\title{
SEASONAL FEATURE OF THE HYDROLOGY OF THE BALI STRAIT ${ }^{1}$ )
}

\author{
by \\ ABDUL Gani ILAHUdE ${ }^{2}$ ) \\ (Manuscript received August 26, 1974)
}

\begin{abstract}
Using the data in the file of the Lembaga Oseanologi Nasional (LON = National Institute of Oceanology), Jakarta, it is shown that the hydrological features at the surface of the Bali Strait are closely related to the meteorological factors of the region. Furthermore, based on the data obtained from the four oceanographical cruises organized by LON in the strait, the features at subsurface layer are analyzed. The influence of the current system south of Java and the upwelling associated with it are also discussed.
\end{abstract}

IKHIISAR

Analisa data yang terdapat dalam arsip Lembaga Oseanologi Nasional, Jakarta, menunjukkan bahwa sifat-sifat hidrologi dari lapisan permukaan Selat Bali erat hubungannya dengan faktor-faktor meteorologi daerah ini.

Sifat-sifat yang terdapat pada lapisan bawah permukaan dianalisa dari data yang diperoleh dari empat pelayaran oseanografi yang dilakukan oleh Lembaga Oseanologi Nasional di Selat Bali. Pembicaraan juga meliputi pengaruh sistem arus disebelah selatan Jawa dan "upwelling" yang berkaitan dengan sistem arus tersebut.

\section{INTRODUCTION}

The seasonal occurrence of the lemuru, Clupea longiceps (C.V.), in the Bali Strait is closely related to the oceanographical condition of the region (SOERJODINOTO 1960). Therefore knowledge on the characteristics of the water masses is important for understanding the population dynamics of the lemuru in the region.

$\left.{ }^{1}\right)$ Originally prepared for the 11th Pacific Science Congress in Tokyo. Only the abstract was submitted.

$\left.{ }^{2}\right)$ Lembaga Oseanologi Nasional, Jakarta. 
However, the oceanographical characteristics, including the hydro-logical properties of the water masses, of the Bali Strait is poorly known. This study attempts to contribute more knowledge on the seasonal features of the hydrology of the Bali Strait.

\section{MATERIALS AND METHODS}

The data of temperature and salinity of the surface water and air temperature collected by the Lembaga Oseanologi Nasional (LON = National Institute of Oceanology), Jakarta, from 1949 to 1958 and the station data obtained during several oceanographical cruises organized by LON in the Bali Strait, were used for the study.

The Indonesian and adjacent waters are devided into a number of one degree-square areas (VEEN 1951, 1953; SOERIAATMADJA 1956). All data obtained from within one degree-square area are grouped and treated as data from one geographical midpoint of that area. The Bali Strait is a region of less than one degree-square and its data are recorded under square No. 0814. The total of 327 salinity, 113 surface water temperature and 113 air temperature values were used, The monthly average values of each parameter in each year were calculated. From these, average values were further averaged to get "normal" monthly values (Table I).

In addition, monthly rainfall data collected by the Lembaga Meteorologi dan Geofisika (LMG = Institute of Meteorology and Geophysics), Jakarta, were also used. These data were obtained from eight coastal stations around the Bali Strait, namely station No. 184, No. 186, No. 203, No. 203 a and No. 204 a in the eastern coast of Jawa and station No. 437, No. $437 \mathrm{c}$ and No. $445 \mathrm{~b}$ in the southwestern coast of Bali (ANONYMOUS 1949-1958). To get an estimate of the monthly rainfall, these values were averaged. From these average values, "normal" monthly values of rainfall (P) over the period of 1949 to 1958 were calculated by the same method as that of hydrological data. Using the "normal" monthly evaporation data (E) given by WYRTKI (1957) for the region south of Jawa, the "normal" monthly values of (E-P) were calculated (Table II).

The station data used were taken from the reports of four oceanographical cruises organized by LON in the Bali Strait (Table III). The position of stations of Cruise I and Cruise II are more or less the same (ILAHUDE 1971). Those of Cruise III are the same with those of Cruise IV (InstituTE OF MARINE RESEARCH 1973. 1974). The station numbers (Fig. 1) of Cruise IV are 1-14 and of Cruise III are 17-30. 


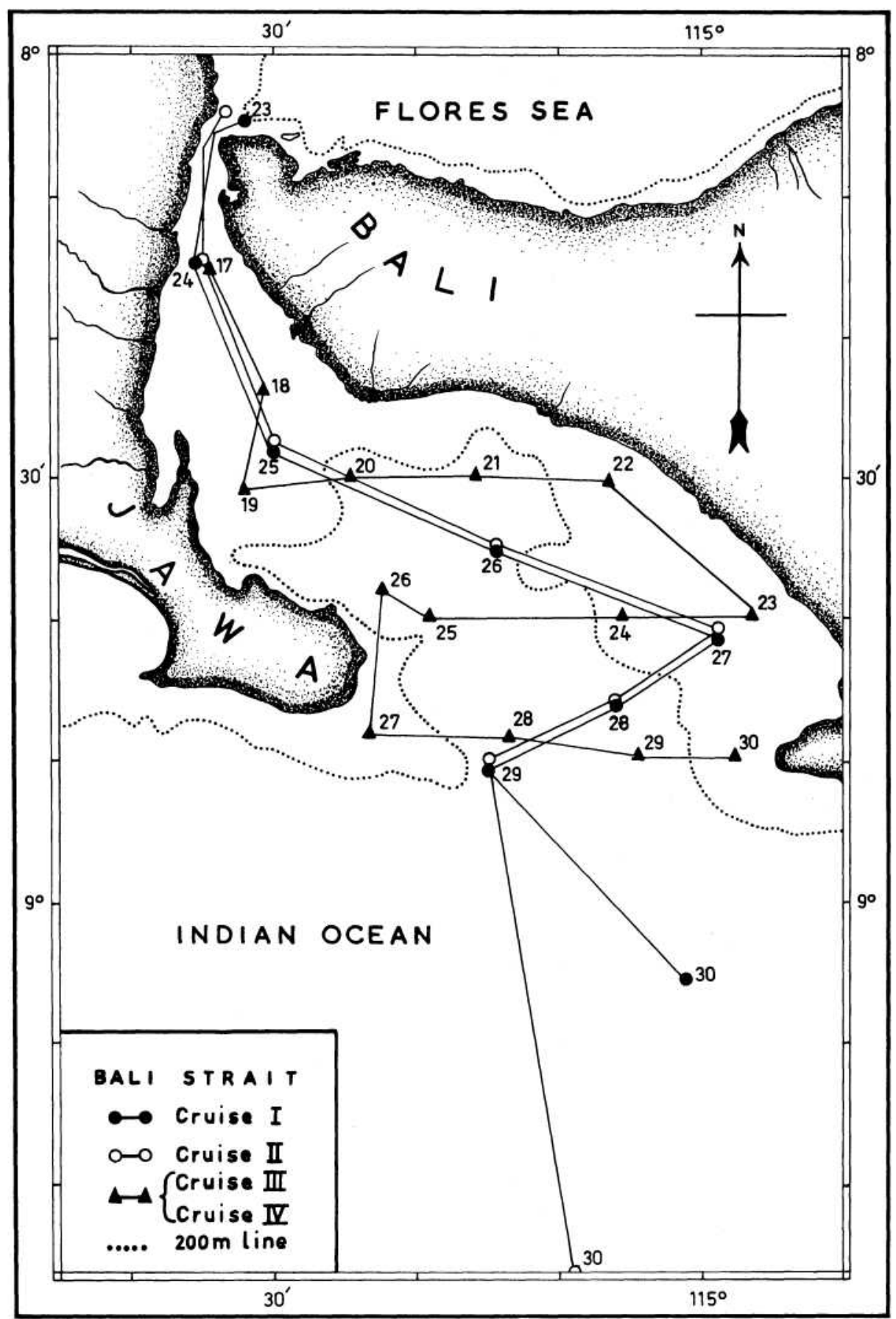

Fig. 1. The oceanographical cruise tracks and the position of stations made by LON in the Bali Strait. Cruise I. Cruise II. Cruise III and Cruise IV. 
40

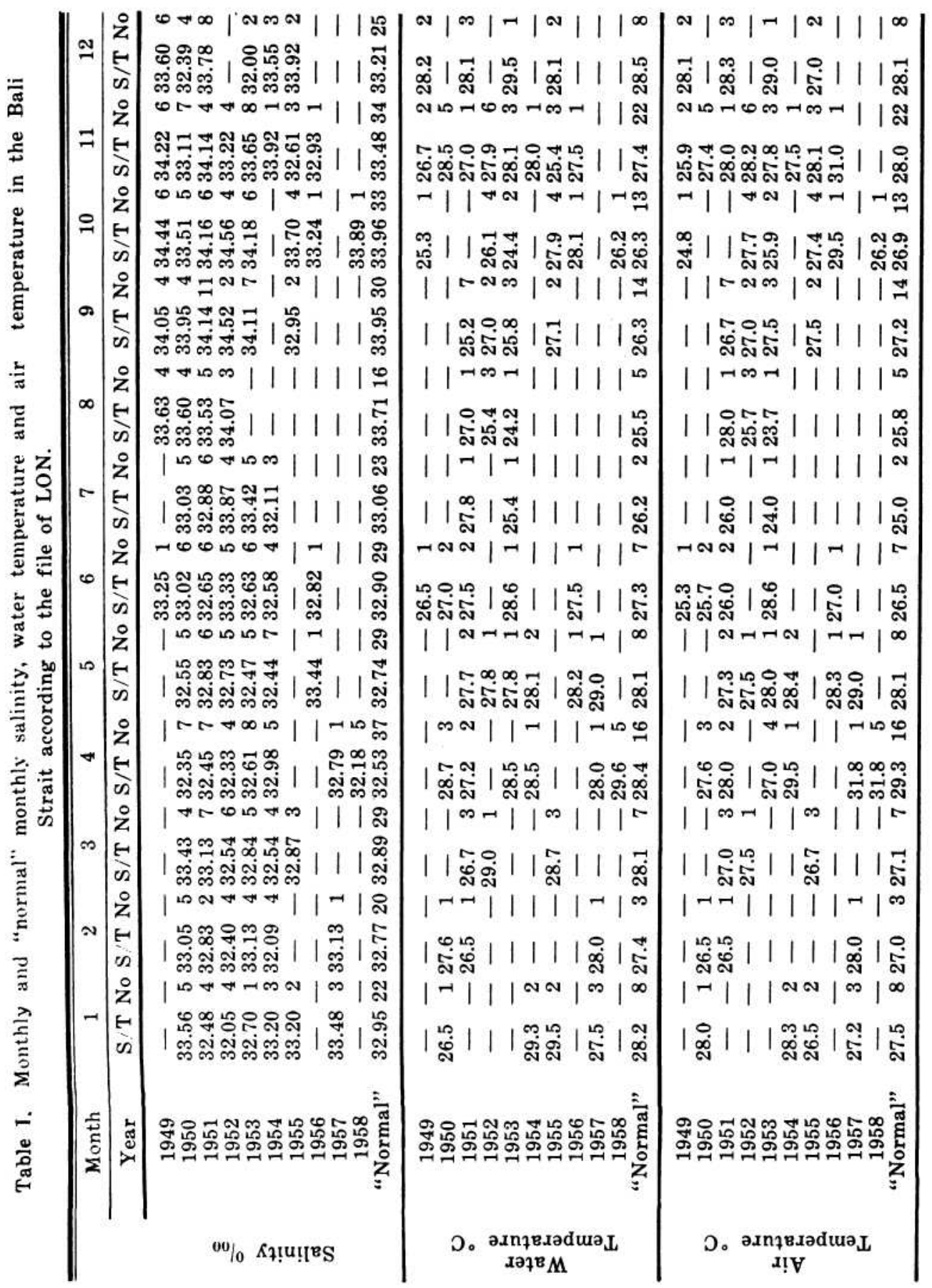




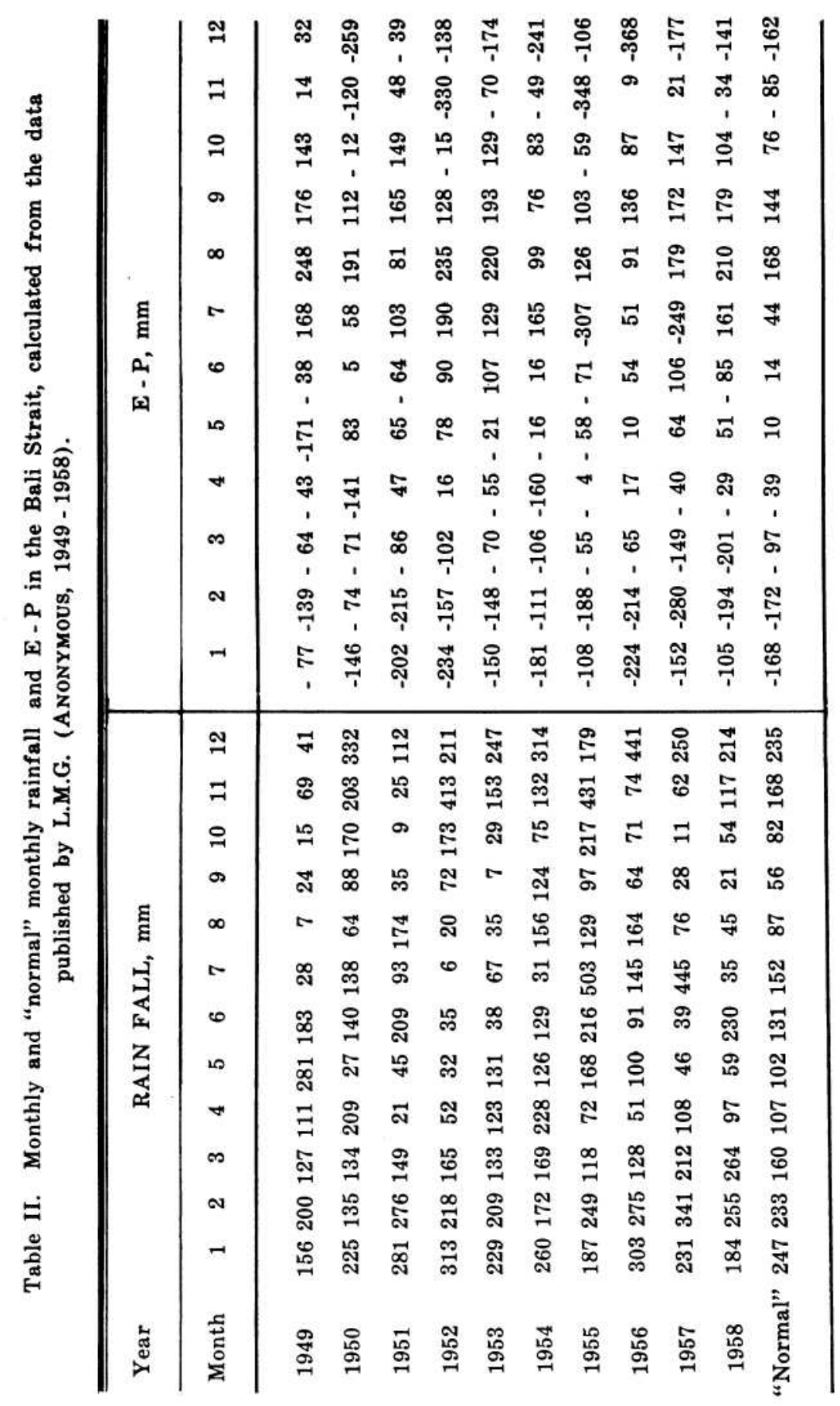


Table III. Oceanographical cruises organized by LON in the Bali Strait.

\begin{tabular}{rlclcc}
\hline Cruise & Month & Year & Ship & No. of Station & Reference \\
\hline I & October & 1964 & Jalanidhi & 8 & ILAHUDE (1971) \\
II & March & 1965 & Jalanidhi & 8 & Ditto \\
III & March & 1973 & Samudera & 14 & INST. MAR. RES (1973) \\
IV & July & 1973 & Samudera & 14 & INST. MAR. RES (1974) \\
\hline
\end{tabular}

\section{RESULT}

\section{a. Seasonal variation}

The "normal" monthly values of the four parameters (surface salinity, surface and air temperature, and E-P) vary seasonally (Fig. 2, Table I and II). For example the water temperature in the northwest monsoon (January to April) is $27.4-28.4{ }^{\circ} \mathrm{C}$, which is in general higher than that in the southeast monsoon (July to October) with 25.5-26.6 ${ }^{\circ} \mathrm{C}$. The seasonal variation of the air temperature is similar to that of the water temperature, in January to April $\left(27.5-29.3{ }^{\circ} \mathrm{C}\right)$ is higher than in July to October $\left(25.0-27.2^{\circ} \mathrm{C}\right)$. The surface salinity in the northwest monsoon (32.53-32.95 \% $\%$ is lower than in the southeast monsoon (33.06$33.96 \%$ ). The variation of surface salinity is in accordance with that of E-P, of which the values in January to April ( -172 to $-39 \mathrm{~mm}$ ) are lower than in July to October ( +44 to $+168 \mathrm{~mm}$ ). Therefore, it is believed that the seasonal hydrological conditions of the Bali Strait are in close relationship to its meteorological condition, at least for the four parameters discussed.

The seasonal variation of the hydrological factors does not occur only in the surface layer but also in the subsurface layers. In March 1965 a water mass with homogeneous high temperature of $28.00-29.00{ }^{\circ} \mathrm{C}$ occupied the whole region of the Bali Strait down to about $100 \mathrm{~m}$ depth (Fig. 3). A sharp thermocline layer where the temperature decreased from 26.50 to $12.00{ }^{\circ} \mathrm{C}$ was found in the deeper part, below this homogeneous layer. The salinity in the thermally homogeneous layer showed large variation $(32.80 \%$ to $34.20 \%$ ) indicating strong mixing with diluted surface water mass. In contrast to the condition in March 1965, the homogeneous layer in October 1964 was quite shallow, with depth of only about $30 \mathrm{~m}$, as indicated by the $26.50{ }^{\circ} \mathrm{C}$ isotherm. The temperature 
in this layer varied between 26.50 to $27.00{ }^{\circ} \mathrm{C}$ which was in general lower than in March 1965. The thermocline layer, also with temperature drop from 26.50 to $12.00{ }^{\circ} \mathrm{C}$, was less sharp, but thicker than in March 1965. The salinity in the homogeneous layer was higher in October 1964 than in March 1965, with small variation and values of around $34.20 \% 0$.

The $100 \mathrm{~m}$ depth of the homogeneous layer in March was indicated by the $3.50 \mathrm{ml} / \mathrm{L}$ and $0.40 \mu \mathrm{gA} / \mathrm{L}$ isopleths of oxygen and phosphate respectively (Fig. 4). The descent of this layer to $30 \mathrm{~m}$ depth in October was indicated by the rise of the $0.40 \mu \mathrm{gA} / \mathrm{L}$ isophosphate to this depth and, to a lesser extent, also by the similar rise of the $3.50 \mathrm{ml} / \mathrm{L}$ isooxygen. The rise of these two isopleths certainly indicates the ascending motion of the water masses which causes the general increase of phosphate and the general decrease of oxygen in the whole water column. The thickening of the thermocline layer in October was indicated by the increase of distance between the 0.40 and $1.60 \mu \mathrm{A} / \mathrm{L}$ isophosphate and the 3.50 and $2.00 \mathrm{ml} / \mathrm{L}$ isooxygen.

This basic pattern of vertical distribution is confirmed by the observations made during Cruise III (March 1973) and Cruise IV (July 1973), representing the conditions in the northwest and the southeast monsoon respectively. The general ascending motion of water masses during the southeast monsoon is indicated by all the isopleths. For example the 26.00 isopycnal rises from $200 \mathrm{~m}$ in March 1973 to $110 \mathrm{~m}$ in July 1973 , the $26.50{ }^{\circ} \mathrm{C}$ isotherm rises from 120 to $20 \mathrm{~m}$, the $34.20 \%$ isohaline from $120 \mathrm{~m}$ to $50 \mathrm{~m}$, the $3.50 \mathrm{ml} / \mathrm{L}$ isooxygen from $120 \mathrm{~m}$ to $30 \mathrm{~m}$, the 0.40 ( $\mu \mathrm{gA} / \mathrm{L}$ isophosphate from $100 \mathrm{~m}$ to $30 \mathrm{~m}$, the 0.50 and 1.00 $\mu g \mathrm{~A} / \mathrm{L}$ isonitrate from the deep part approaches the shallow part, and the $5.00(\mu \mathrm{gA} / \mathrm{L}$ isosilicate rises from $100 \mathrm{~m}$ to $20 \mathrm{~m}$. These facts indicate the importance of upwelling in bringing about the seasonal differences of the hydrology of the Bali Strait (Plates 1 -14).

In regard to the influence of the E-P on salinity, a rough calculation following the method of BERLAGE (1927) shows that its extent is also limited to several meters below the surface. Based on the E-P data (Table II) and the increase of salinity from 32.80\% (March) to $34.20 \%$ (October) or vice versa (Fig. 3), it is calculated that the E-P is capable of altering the surface salinity of the water column down to the depth of only 10 to $15 \mathrm{~m}$. However, the seasonal variation of temperature and salinity occurs also in deep layers, down to at least $100 \mathrm{~m}$ depth. The salinity variation at this depth may be brought about by two processes, i.e. the introduction of another source of fresh water, such as rivers or coastal drainage to the Bali Strait, and the introduction of low salinity 
water mass in March and high salinity water mass in October to the region. A simple calculation indicates that the first process is quite unlikely. The total volume of the Bali Strait between $20-100 \mathrm{~m}$ is about $145,800,000,000 \mathrm{~m}^{3}$. The average salinity at this layer in October is about $34.35 \%$. If this value has to decrease to the March average value of $33.44 \% 00,3,967,600,000 \mathrm{~m}^{3}$ of fresh water is needed. This amount has to be supplied in 5 months period or at the rate of $306 \mathrm{~m}^{3} / \mathrm{sec}$. There is no river(s) or any other drainage system capable of delivering fresh water up to that amount known to exist in the Bali Strait. Moreover the system has to be capable of withdrawing that water again to bring back the salinity to its October value. Therefore, the second process is most likely to be the main agent causing the variation.

\section{b. Water circulation}

Water masses are generally introduced to a particular region through ocean currents. According to WYRTKI (1961), in the surface current system in the greater part of south of Jawa, the westward flowing South Equatorial Current is dominant throughout the year (Fig. 5). An eastward flowing coastal current called the Jawa Coastal Current (SURIAATMADJA 1957), which develops during the northwest and the first transition monsoon (December to June), is flowing in a limited area very close to Jawa Island. As a result of mixing with fresh water coming from Jawa, the temperature in this current region is high (about $29.0^{\circ} \mathrm{C}$ ) and the salinity is low (less than $33.5 \%$ ). This situation has been confirmed by the observations made during the Cruise Around Jawa I and II (Fig. 6). The low salinity water is still present in the western part of south of Jawa until October. During the southeast and the second transition monsoon (July to November) the Jawa Coastal Current vanishes and is replaced by the extention of the South Equatorial Current with low temperature and high salinity water mass of the Indian Ocean (Fig. 5). During the northwest monsoon (December to April) the discontinuity layer in the region of the Jawa Coastal Current is tilted downward toward the Bali Strait (Fig. 7). The condition is caused primarily by the adjustment of the field of mass to the field of current and secondarily by the upwelling occurring at the divergence zone between the two currents. During this season the Jawa Coastal Current brings low salinity and high temperature water masses into the Bali Strait.

The possibility of upwelling in the divergence zone and the deepening of the thermocline layer, which in this particular region reflects also the deepening of the discontinuity layer toward the Jawa coast, have been 


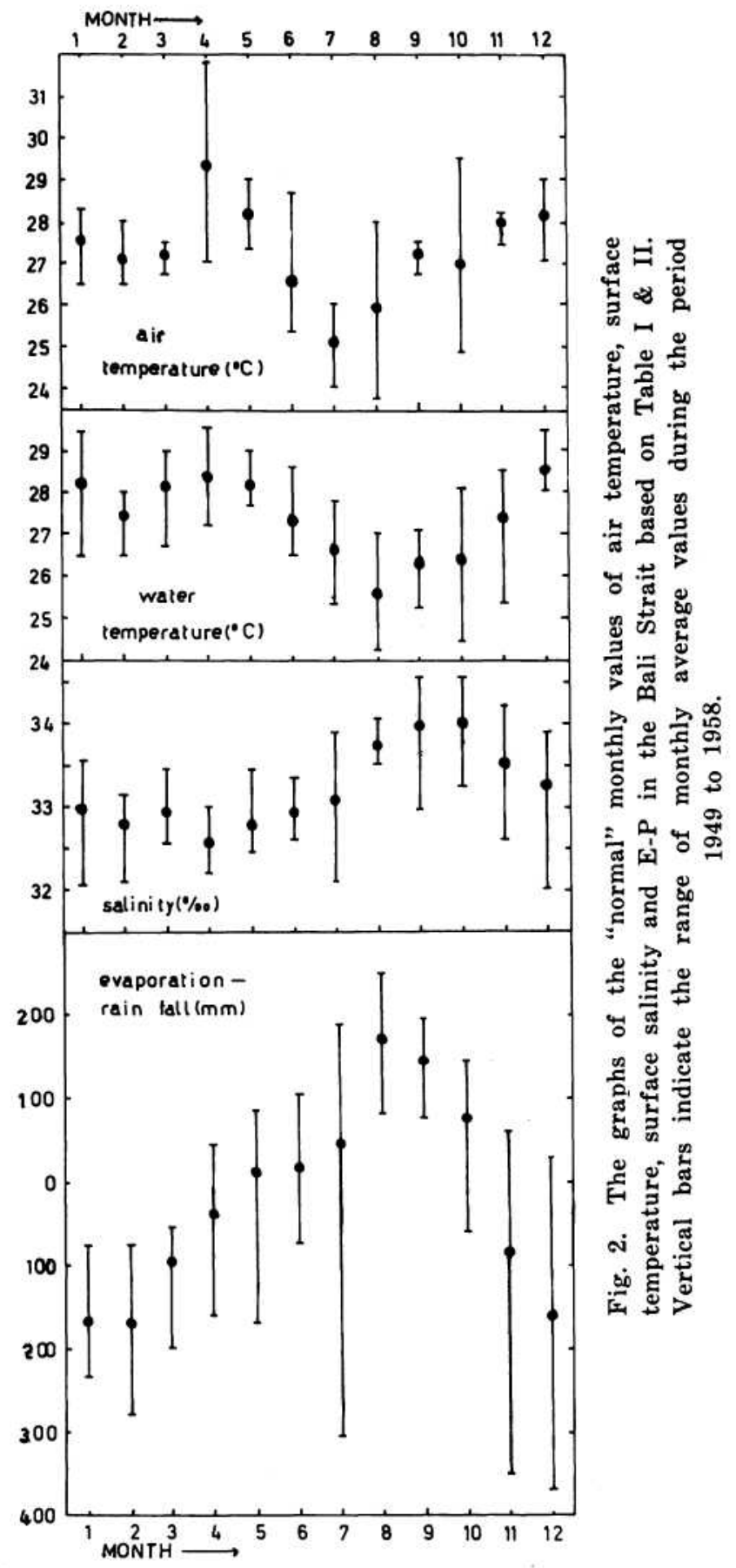



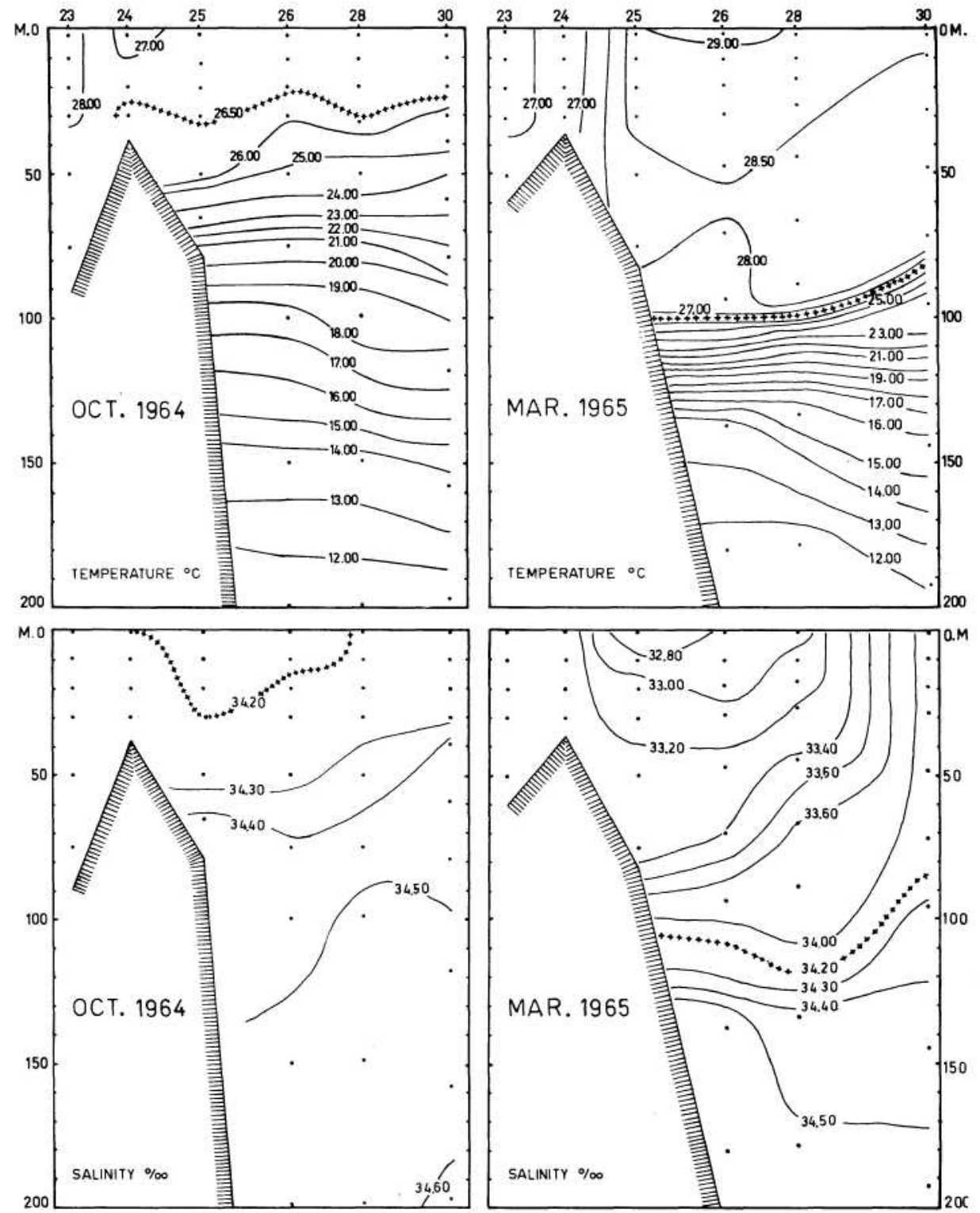

Fig. 3. The vertical cross sections of temperature and salinity in the Bali Strait for October 1964 and March 1965. The dots indicate the observation depths, the numbers on the top indicate the stations and the numbers on the side indicate the depths in $\mathrm{m}$. 

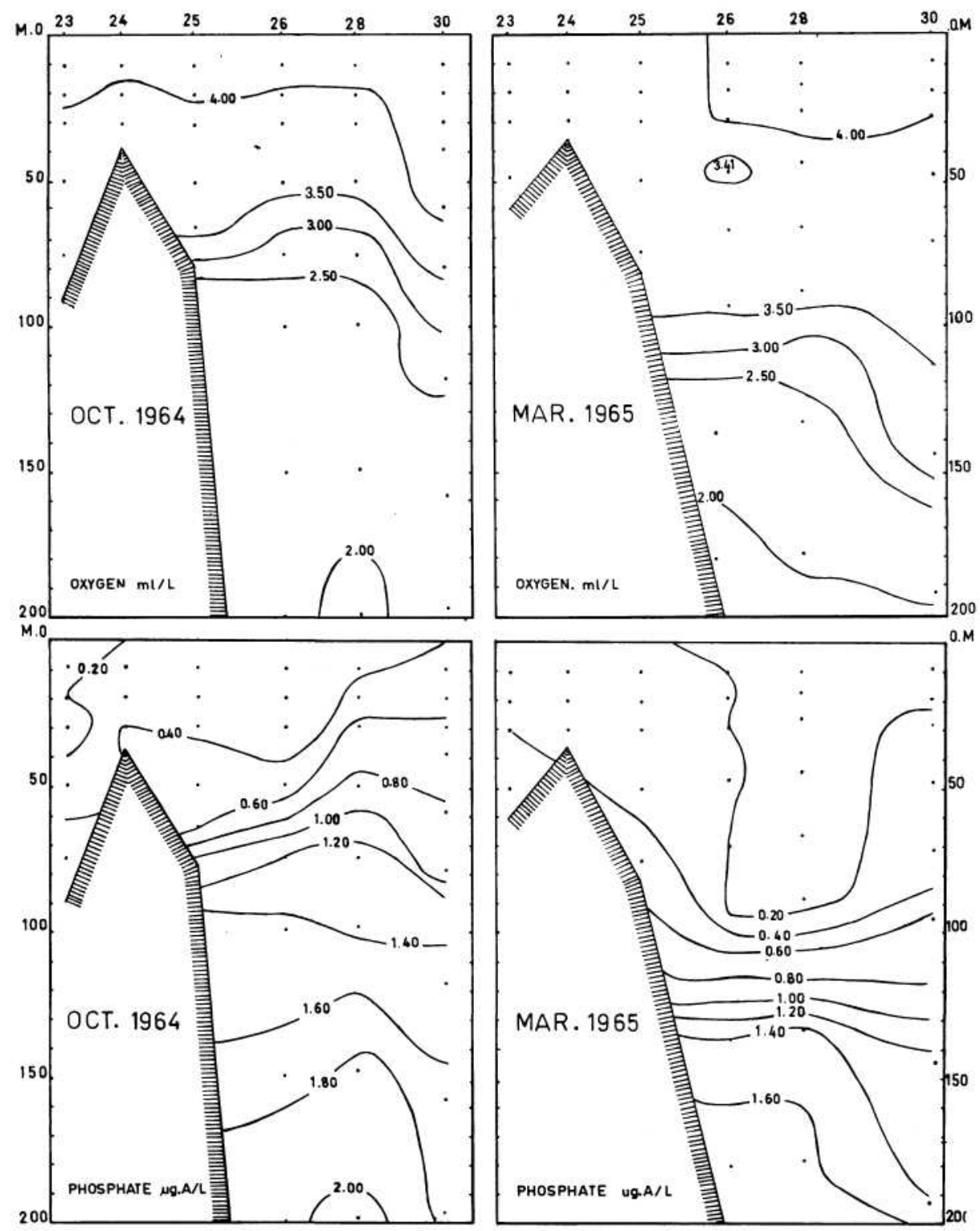

Fig. 4. The vertical cross section of dissolved oxygen and phosphate in the Bali Strait for October 1964 and March 1965. Legend is as in Fig. 3. 


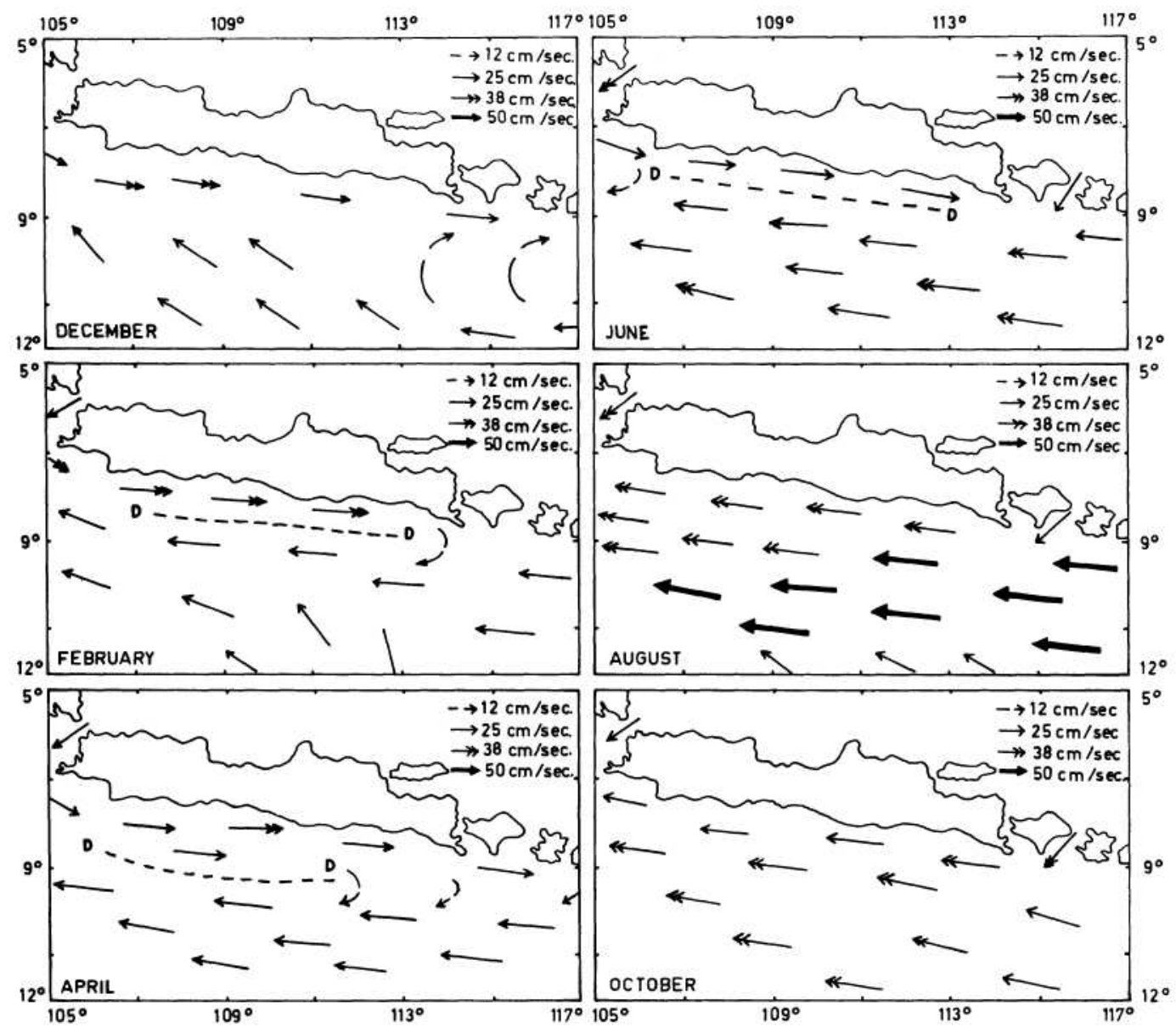

Fig. 5. The current system south of Jawa according to WYRTKI (1961). DD indicates the divergence zone between the Jawa Coastal Current and the South Equatorial Current. 


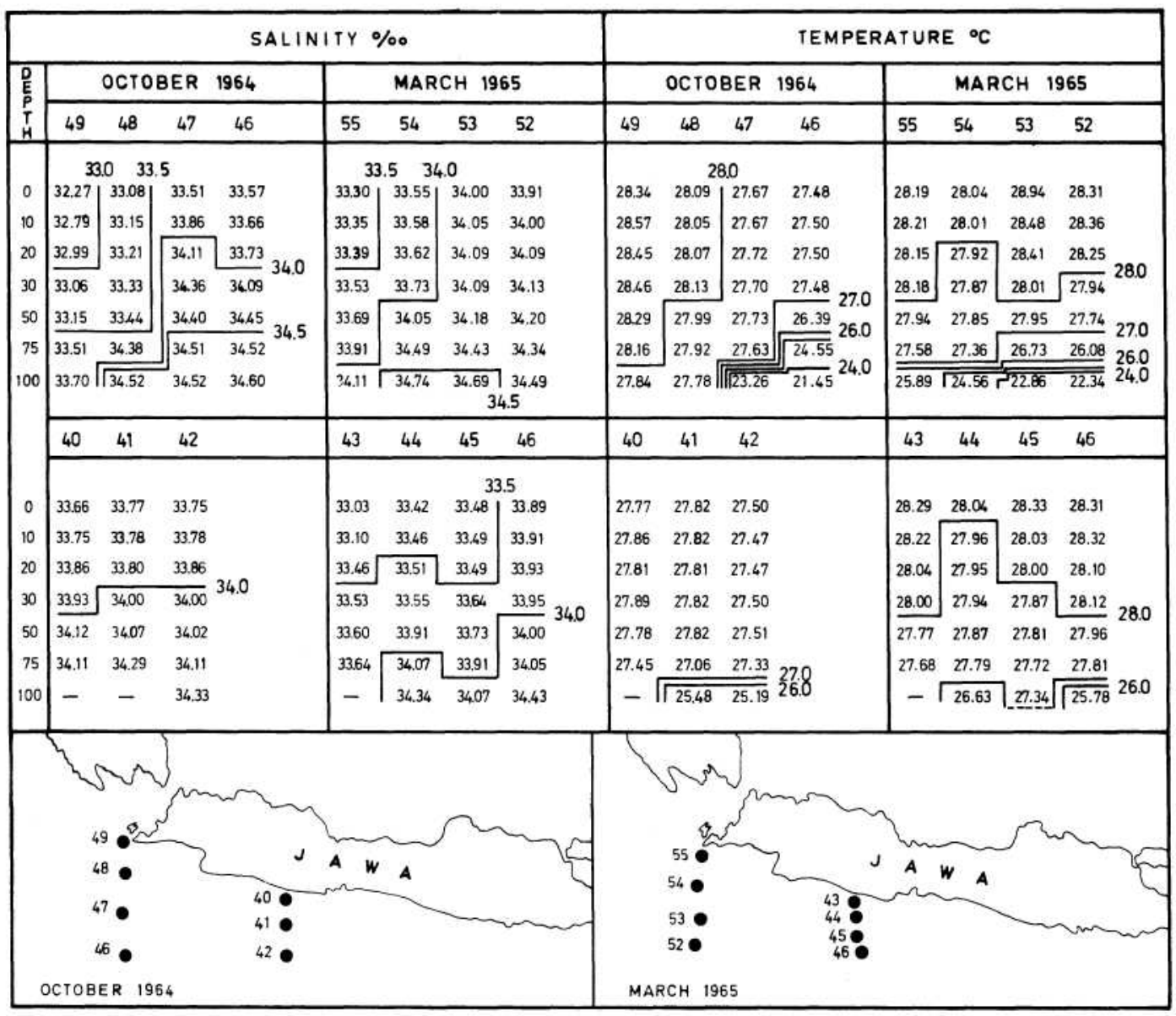

Fig. 6. The salinity and temperature off the south coast of Jawa. The inserted maps show the position of stations in October 1964 and March 1965. Data from ILAHUDE (1971). 
suggested by SOERIAATMADJA (1957). As a consequence, in the northwest monsoon the homogeneous layer in the Bali Strait becomes deeper and the thermocline layer becomes sharper (Fig. 3):

During the southeast monsoon (June to October) the discontinuity layer is tilted upward all the way to the Bali Strait, mainly due to the large scale upwelling process occurring in the south of Jawa to Sumbawa (WYRTKI 1962). During this period the South Equatorial Current brings high salinity and low temperature water masses to the Bali Strait, while the homogeneous layer becomes shallower and the thermocline layer becomes thicker and less sharp (Fig. 3).

The exact features of the currents through which the water masses enter and leave the Bali Strait need further study. However, there is indication that to some extent the local monsoon winds and the tides determine those features. Due to the narrowness of the strait, the current system could simply be an alternating northwestward and southeastward flow in harmony with the flood and ebb period of the tide, or could be a complex circuitous system of flow as suggested by the arrows in Figs. 8-11. The arrows indicating the flow in these figures are constructed according to the assumption that the pattern of the isopleths of the hydrological distribution to some degree reflects also the pattern of the flow. By comparing the distribution pattern among the parameters, the most likely direction of flow was then determined. During the northwest season a clockwise flow in the Bali Strait brings low salinity water from the Indian Ocean (Figs. 8-9), while during the southeast season the opposite situation occurs wherein an anticlockwise system of flow introduces high salinity water from the Indian Ocean into the Bali Strait (Figs. 10-11). At this stage such a flow is still partly hypothetical and if it does occur, its occurrence could be aided by the "right" condition of the local tide. For example the flood tidal current would strengthen the northwestward flow along one coast and the ebb tidal current would strengthen the southeastward flow along the other coast of the strait.

The tidal current in the northern entrance of the Bali Strait is quite strong (ANONYMOUS 1952). However due to its narrowness (1 km) the entrance effectively cuts off the water exchange between the Flores Sea and the Bali Strait. The temperature and the salinity of Cruise I and of Cruise II clearly indicate the absence of relationship between the Flores Sea (Station No. 23) and the Bali Strait (Station No. 24 and 25) (Table IV). 


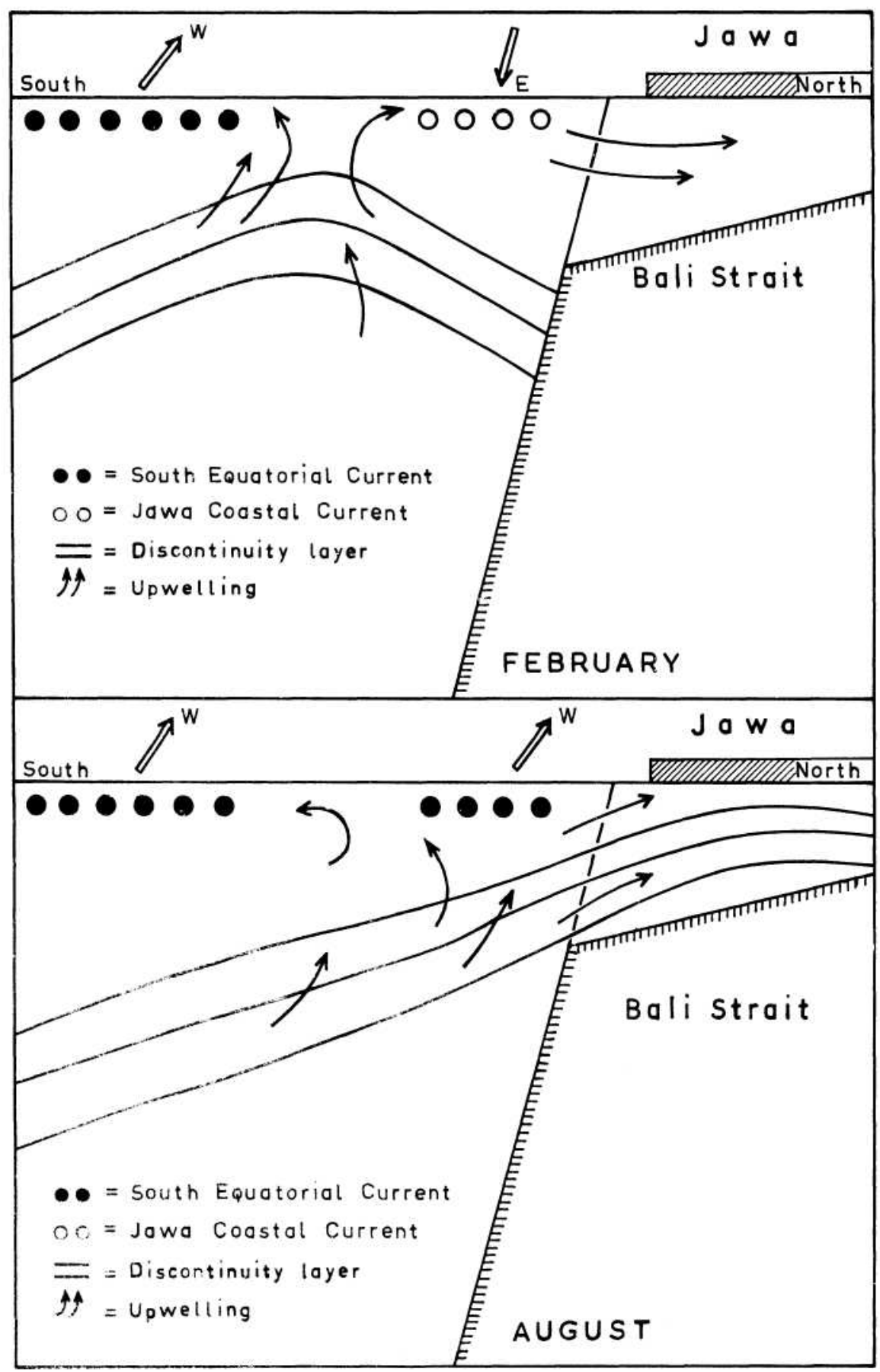




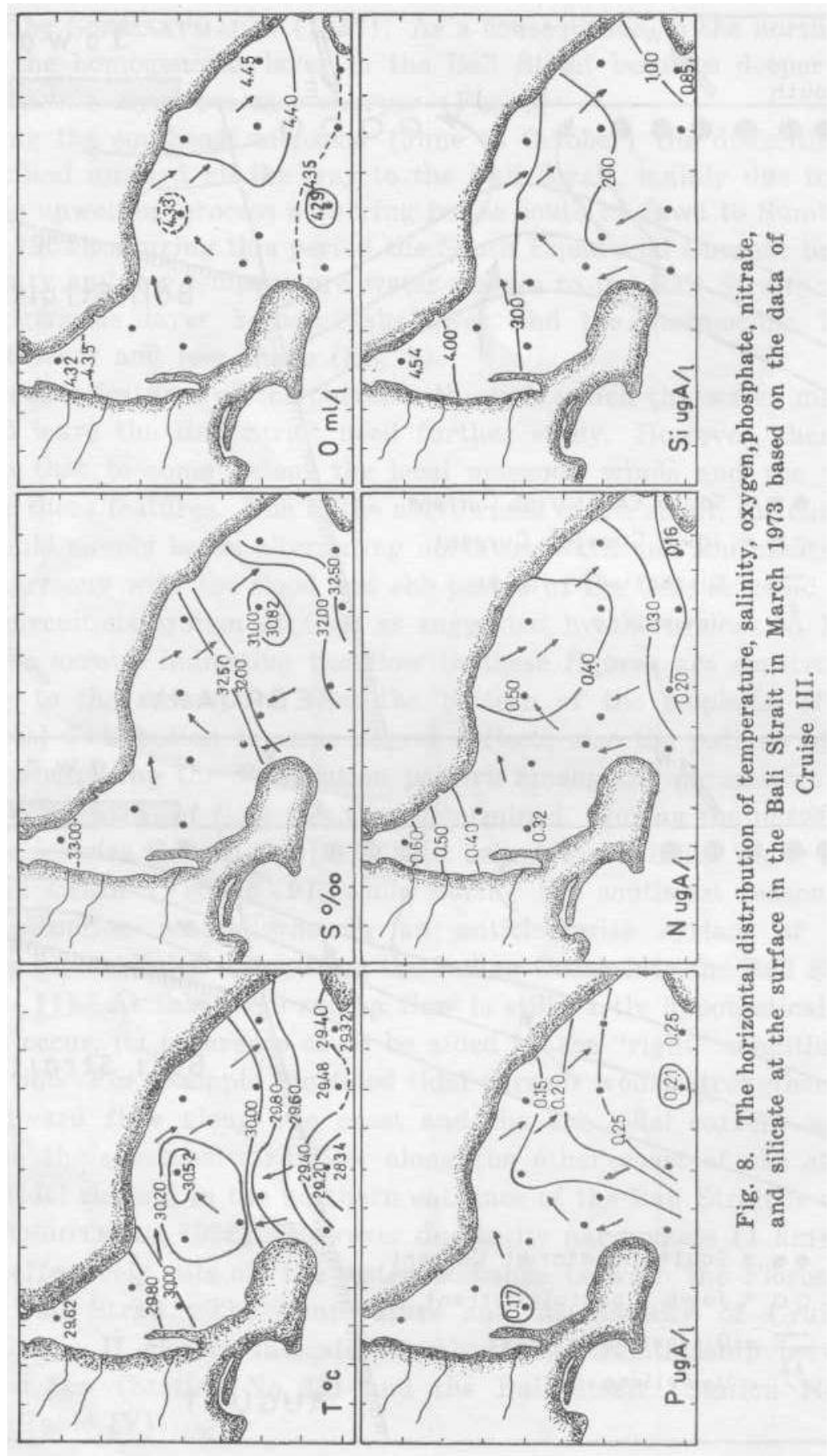




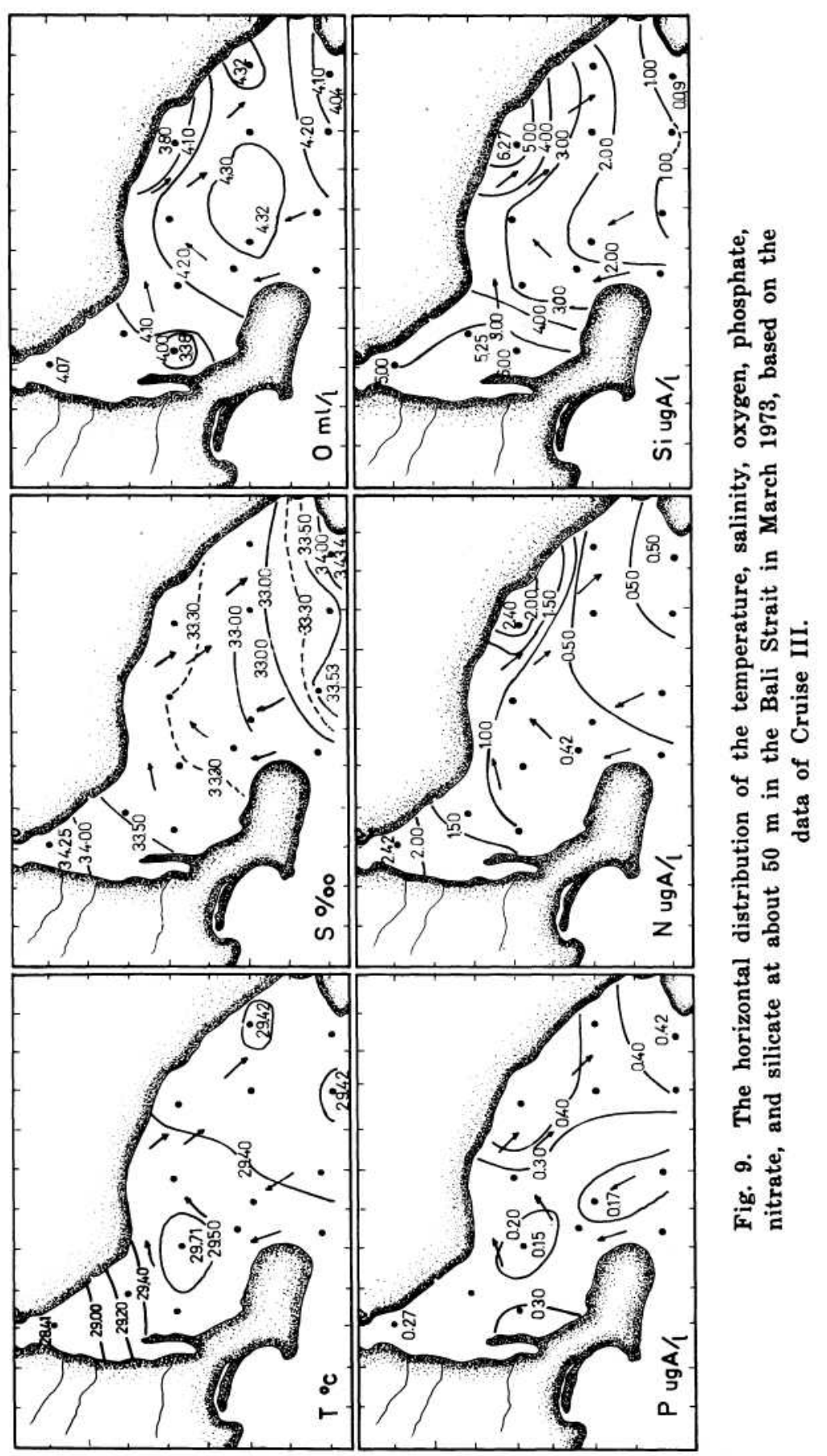




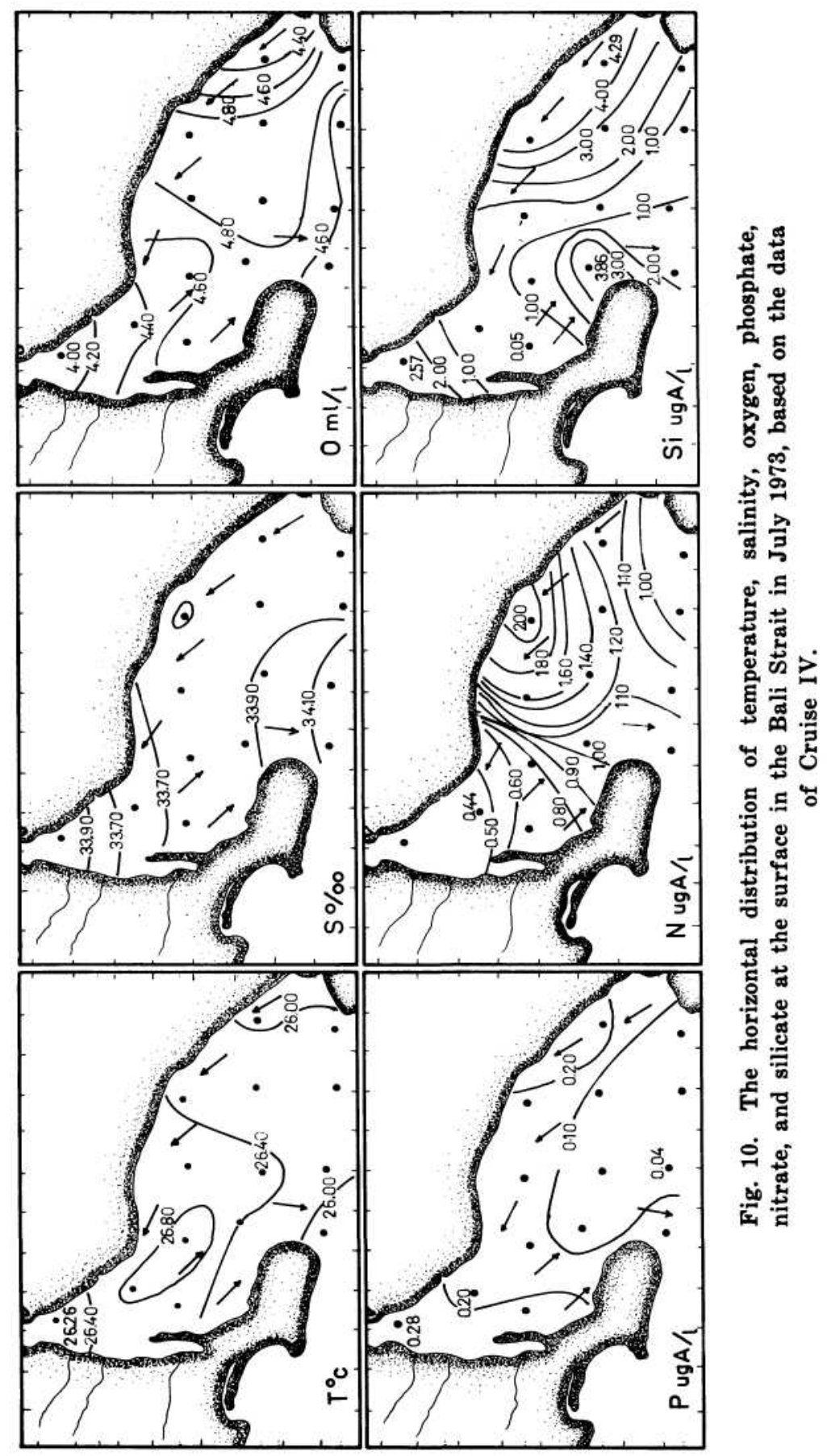




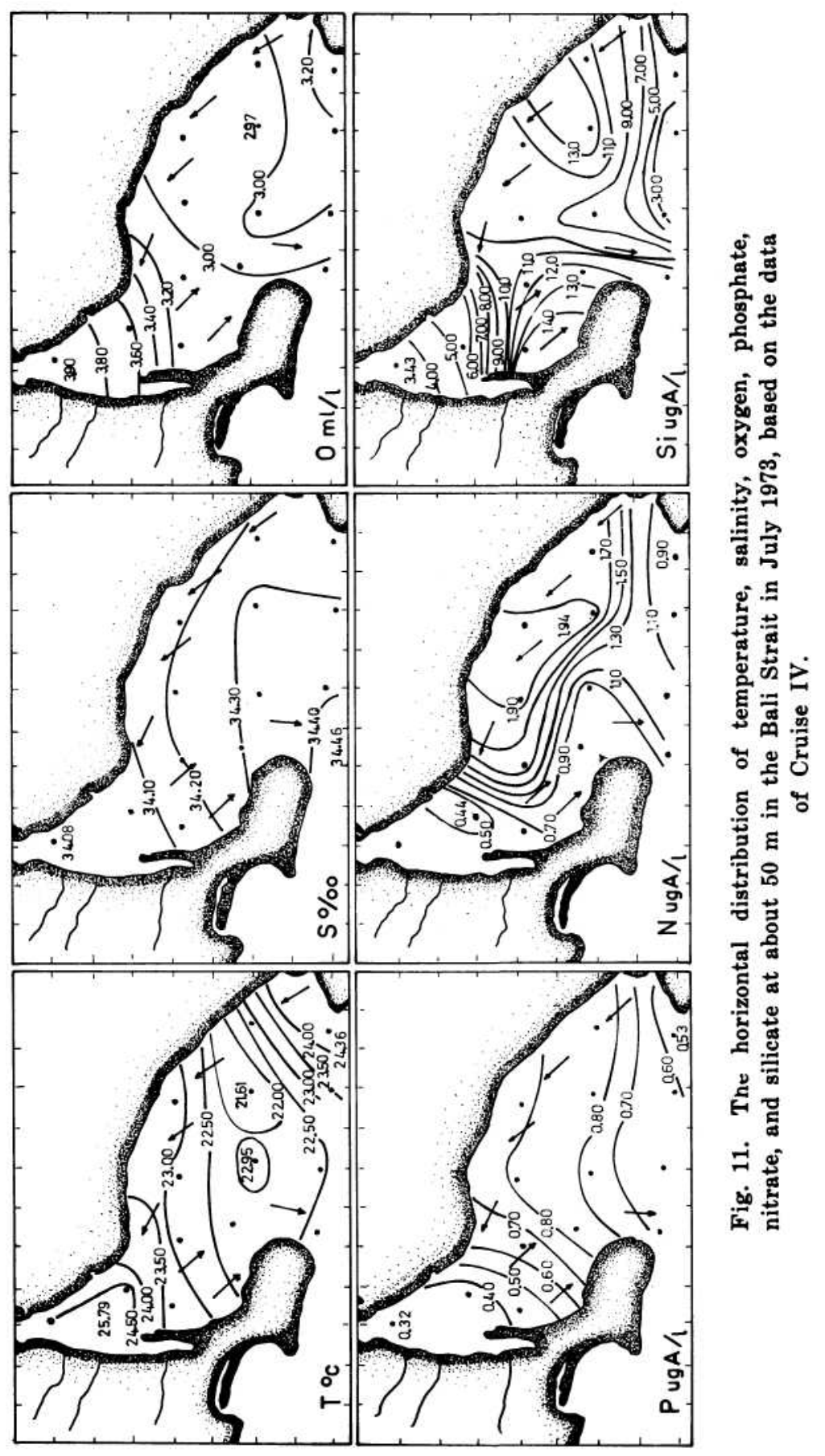


Table IV. The salinity and temperature in the northern entrance of the Bali Strait during Cruise I (October 1964) and Cruise II (March 1965).

\begin{tabular}{|c|c|c|c|c|c|c|c|c|c|c|c|c|}
\hline \multirow{3}{*}{$\frac{\text { Depth }}{\text { St. }}$} & \multicolumn{6}{|c|}{ Cruise I } & \multicolumn{6}{|c|}{ Cruise II } \\
\hline & \multicolumn{3}{|c|}{ Salinity $\%$} & \multicolumn{3}{|c|}{ Temperature ${ }^{\circ} \mathrm{C}$} & \multicolumn{3}{|c|}{ Salinity $\%$} & \multicolumn{3}{|c|}{ Temperature ${ }^{\circ} \mathrm{C}$} \\
\hline & 23 & 24 & 25 & 23 & 24 & 25 & 23 & 24 & 25 & 23 & 24 & 25 \\
\hline 0 & 34.18 & 34.20 & 34.14 & 28.05 & 27.12 & 26.89 & 33.32 & 33.24 & 32.03 & 27.38 & 26.65 & 28.97 \\
\hline 10 & 34.22 & 34.22 & 34.14 & 28.07 & 27.00 & 26.64 & 33.22 & 33.29 & 32.97 & 27.28 & 26.69 & 28.82 \\
\hline 20 & 34.22 & 34.22 & 34.18 & 28.07 & 26.83 & 26.65 & 33.23 & 33.26 & 33.03 & 27.37 & 26.61 & 28.73 \\
\hline 30 & 34.22 & 34.27 & 34.20 & 28.05 & 26.15 & 26.62 & 33.30 & 33.30 & 33.12 & 27.22 & 26.78 & 28.72 \\
\hline
\end{tabular}

The observations made during Cruise III and IV showed the same discontinuity within the water column of station No. 18 and No. 3 similar to those found at station No. 24. The absence of the influence of the water mass of the Flores Sea on that of the Bali Strait is also indicated by the horizontal distribution of the hydrological parameters (Figs. 8-11). It is concluded, therefore, that the southern entrance is the opening through which outside water masses can enter the Bali Strait in a significant quantity.

\section{DISCUSSION}

Comparing the "normal" surface salinity of the Bali Strait (Fig. 2) with that of the eastern part of the southcoast of Jawa (SOERIAATMADJA 1957), it is found that basically, the pattern of the annual salinity variation in both regions is similar. The salinity increases from its primary April minima $(32.50 \%$ and $32.8 \%$ ) to its primary October maxima $(34.00 \%$ and $34.4 \%$ ). In November the salinity in both region decreases suddenly to its secondary minima and maxima. However, the increase and decrease of the salinity in these regions show notable differences. The secondary minimum in the Jawa coast $(33.1 \%$ occurs in November while in the Bali Strait $(32.77 \%$ ) in February. The secondary maximum in the Jawa coast $(33.8 \%$ occurs in January, while that of the Bali Strait (32.89 \% $)$ in March (Fig. 2, Table I). Thus, the situation occurs later in the Bali Strait than in the eastern part of Jawa coast. The surface salinity in the Bali Strait is lower than that in the eastern part of the Jawa coast and the duration and 
the salinity differences between the secondary extreem values are shorter and smaller in the Bali Strait than in the Jawa coast. In the Bali Strait the secondary maximum (March) is very close to the primary minimum (April).

The explanation of SOERIAATMADJA (1957) on the increase of salinity in the eastern part of the Jawa coast from April to October, by the replacement of Jawa Coastal Current with the South Equatorial Current that brings the high salinity water mass to the coastal region (Fig. 5) and by the increase of E-P during the period May through October (Fig. 2), and the explanation on the decrease of salinity in November, which is due to the onset of the Jawa Coastal Current that brings low salinity water to the region, while the maximum in January is due to the northwest monsoon upwelling (Fig. 5 and Fig. 7), are also valid for the Bali Strait. However, due to the fact that the Bali Strait is relatively a closed region compared to the open Jawa coast, any mixing process occurring in it, to a certain degree, will be confined to that region alone. As a result the influence of the rainfall over the Bali Strait and adjacent coast from November to April (Table II) in decreasing the salinity is stronger, while the influence of the northwest monsoon upwelling in increasing the salinity is weaker. This fact explains the notable difference between the two regions.

The present data clearly indicate the strong influence of the southeast monsoon upwelling in south of Jawa on the hydrology of the Bali Strait (WYRTKI 1962). This upwelling causes the general drop of temperature and oxygen and the general rise of salinity, inorganic phosphate, nitrate and silicate of the Bali Strait (Fig. 3, 4, 8-11: Plates 1-14), though at first it escaped the author's attention (ILAHUDE, 1970). High rate of production of 28.0 to $44.7 \mathrm{mg} \mathrm{C} / \mathrm{hr} / \mathrm{m}^{3}$ due to upwelling has been recorded by SOEGIARTO and NONTJI (1966) from the south of the Bali Strait.

The annual variation of the "normal" surface temperature of the Bali Strait is of an inversed pattern with that of salinity variation (Fig. 2). The maxima occur in April and December, while the minima in February and August. The occurrence of these two minima can be explained by the influence of stronger winds which usually occur during the northwest and the southeast monsoon. The April maximum is probably due to the heating process, facilitated by the calm condition during the transition period. The maximum in December is at present difficult to be explained. 
Upwelling affects also the surface temperature. During the upwelling period (August to November) the water is colder than the air (Table V).

Table V. The "normal" water and air temperature in the Bali Strait.

\begin{tabular}{ccccccccccccc}
\hline Month & 1 & 2 & 3 & 4 & 5 & 6 & 7 & 8 & 9 & 10 & 11 & 12 \\
\hline Water & 28.2 & 27.4 & 28.1 & 28.4 & 28.1 & 27.3 & 26.6 & 25.5 & 26.3 & 26.3 & 27.4 & 28.5 \\
Air & 27.5 & 27.0 & 27.1 & 29.3 & 28.1 & 26.5 & 25.0 & 25.8 & 27.2 & 26.9 & 28.0 & 28.1 \\
\hline Difference + & + & + & - & 0 & + & + & - & - & - & - & + \\
\hline
\end{tabular}

The decrease of dissolved oxygen as well as the increase of nitrate and silicate due to the upwelling in July 1973 are significant at $50 \mathrm{~m}$ depth only (Figs. 10-11). At the surface, the March and the July values of nitrate and silicate are quite comparable, while those of oxygen are higher in July than in March 1973. Accoding to NONTJI (personal communication) the average saturation values of oxygen is relatively higher in July than in March, parallel to the concentration of surface chlorophyl-a which is also higher in July than in March. This phenomenon may be explained from the high activity of the phytoplankton in the Bali Strait.

\section{CONCLUSIONS}

The study points out that three processes are important in causing the seasonal hydrological characteristics of the Bali Strait. At the subsurface layer the seasonal variation is brought about by the current system south of Jawa and the upwelling associated with the system. At the surface layer the seasonal variation is related to the meteorological condition and the upwelling.

The study also points out the need of further investigation on the nature of the current system within the Bali Strait, the sea-air interaction, and the northwest monsoon upwelling south of Jawa.

\section{ACKNOWLEDGEMENT}

Thanks are due to Lieutenant Colonel (I.N.) SJAMSOEDDIN former commander of the R.V. Jalanidhi and Mr. H. L. W. LONDT, commander of the R.V. Samudera and their crews, for the good cooperation in executing 
the observations in the Bali Strait; to colleagues at the Plankton and Productivity Laboratories, Lembaga Oseanologi Nasional, for their cooperation in carrying out oceanographical work during the four cruises; and to those who helped in one way or another.

Finally, appreciation to Dr. KLAUS WYRTKI for his valuable comments.

\section{REFERENCES}

AnONYmous 1949 -1958. Pemeriksaan hujan di Indonesia 1947 -1958. Vols. 66 - 71. Institute of Meteorology and Geophysics, Jakarta.

--------- 1952. Sailing Directions. Celebes, Southeast Borneo, and Java. H.O. Pub. 165: 108-109.

Berlage, H. P. 1927. Monsoon-currents in the Java Sea and its entrances. Konin. Magnet. Met. Observat. te Batavia. Verhandelingen 19: 1-28, 61 charts.

ILAHUDE, A. G. 1966. Oceanographic observation in Bali Strait. Abstract Proc. $11^{\text {th }}$ Pacific Set. Congress, Tokyo 2: 18.

------1970. On the occurence of upwelling in the Southern Makassar Strait. Mar. Res. Indonesia 10: 3-53.

------ 1971. Oceanographic Station List 1963 -1966. Inst. Mar. Res., Oceanogr. Cruise Rep. Special Issue: 1-67.

INSTITUTE OF MARINE RESEARCH 1973. Hydrological, plankton and pigment observations in the Maluku Sea and in the Bali Strait. Oceanogr. Cruise Rep. 11: 1-38.

------- (1974). Hydrological, plankton and pigment observations in the Bali Strait, around Gag Island and in the Banda Sea. Oceanogr. Cruise Rep. 13: 1 - 48.

Soegiarto, A. and A. Nontu 1966. A seasonal study of primary marine productivity in Indonesian waters. (Paper presented to the 11th Pacific Science Congress in Tokyo).

SoERIAATMADJA, Rd. E. 1956. Seasonal fluctuations in the surface salinity off North Coast of Java. Mar. Res. Indon. 1: 1-19.

-1957. The coastal current south of Java. Mar. Res. Indonesia 3: 41-55.

SoerJodinoto , R. 1960. Synopsis of biological data on lemuru Clupea (Harengula) longiceps (C.V.) FAO Fisheries Biology Synopsis (FB/S 15) 15: 313-328.

VeEN, P. Ch. 1951. Surface salinities in the Indonesia Archipelago and adjacent waters. Org. Sci. Res. Bull. S3: 1-20.

1953. Preliminary charts of the mean salinity of the Indonesian Archipelago and adjacent waters. Org. Set. Res. Bull. 17: 1-47.

WyrtKi, K. 1957. Precipitation, evaporation and energy exchange at the surface of the Southeast Asian Waters. Mar. Res. Indonesia 3: 7-40.

------ 1961. Physical oceanography of the Southeast Asian Waters. Naga. Report 2: 1-195.

1962. The upwelling in the region between Java and Australia during the southeast monsoon. Austr. J. Mar. Freshw. Res. 13(3): 217-225. 
60

MAR. RES. INDONESIA 15

Plate 1

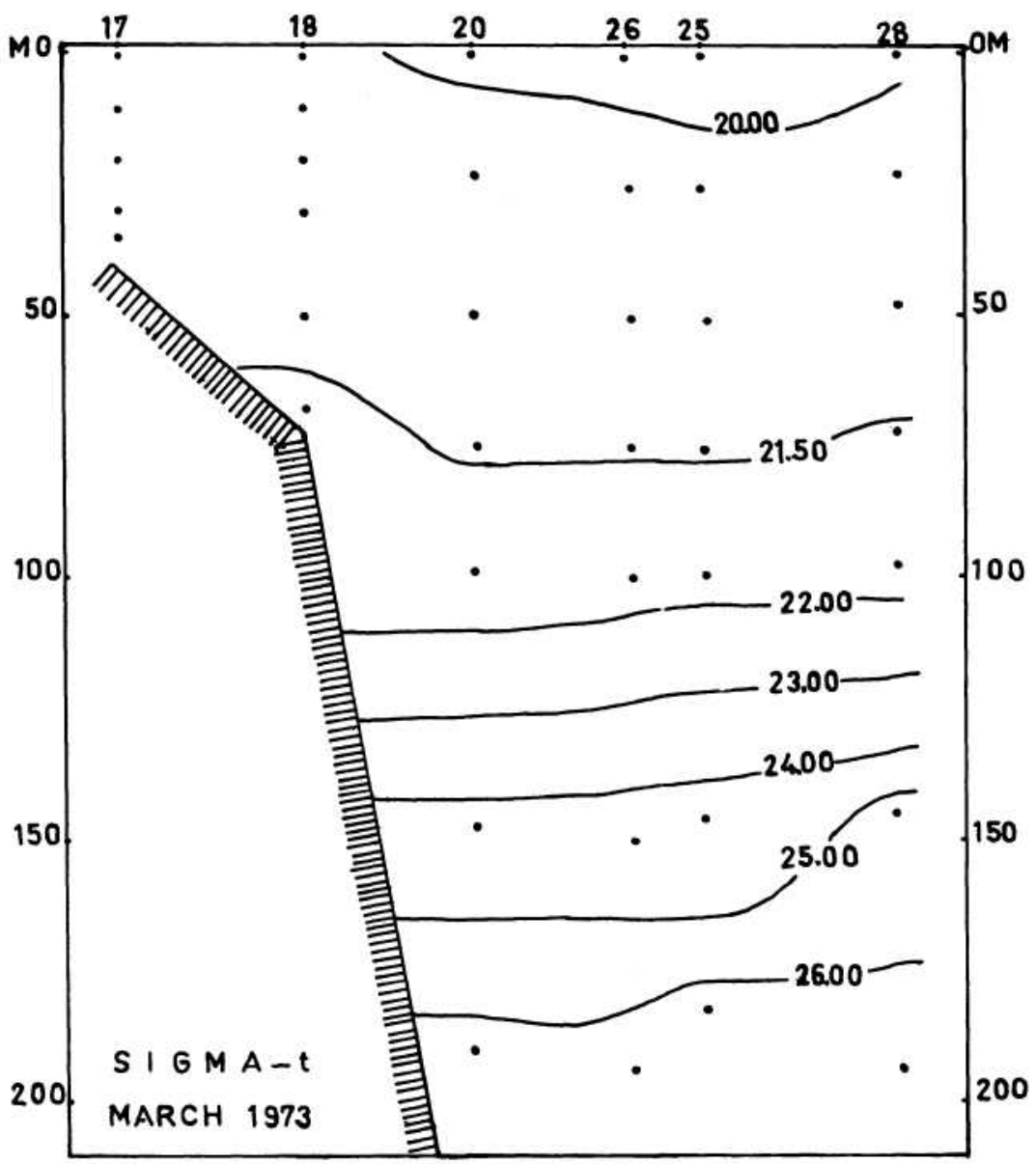

Cross Section of Sigma-t (density) in the Bali Strait in March 1973. 


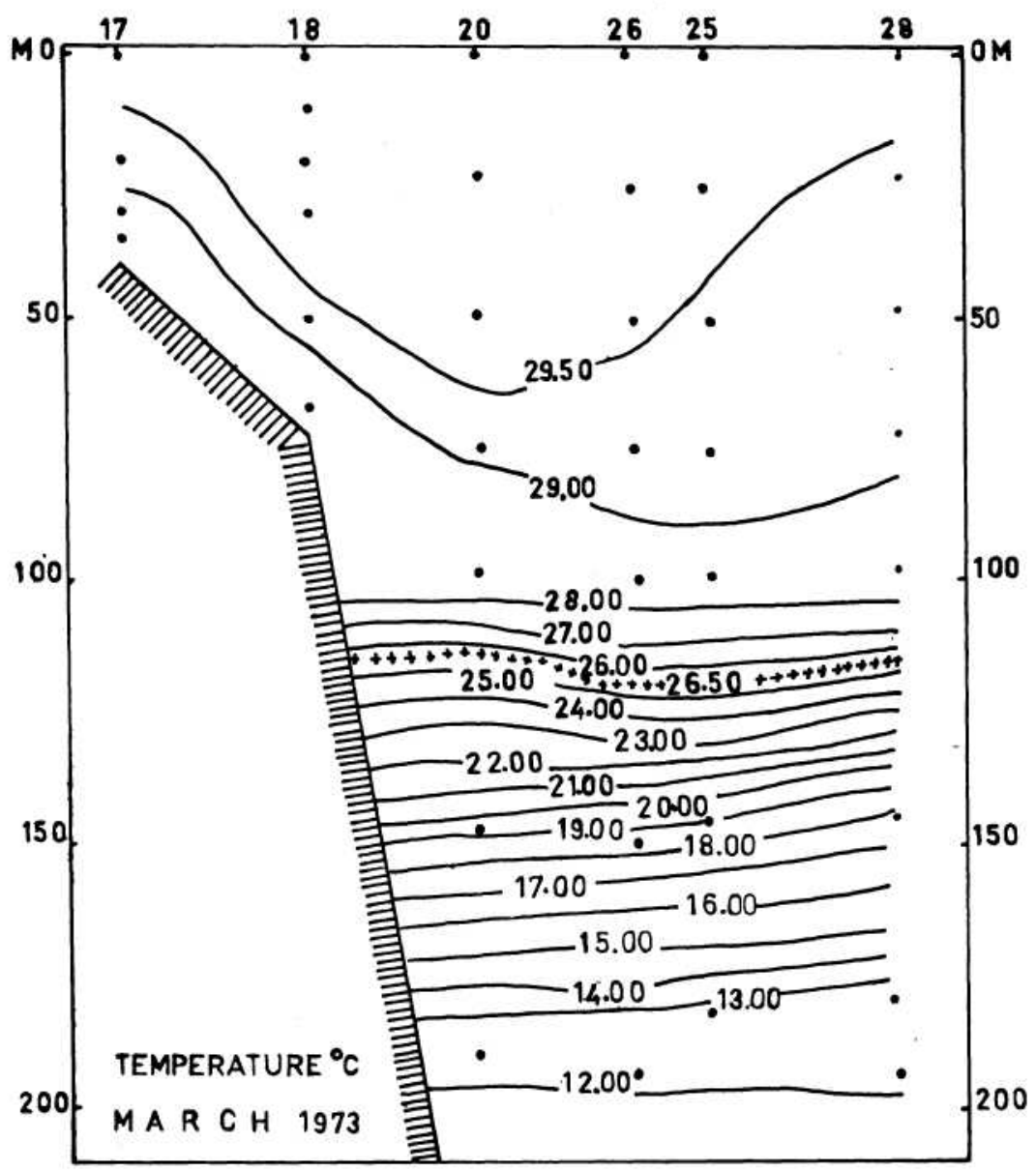

Cross Section of temperature in the Bali Strait in March 1973. 


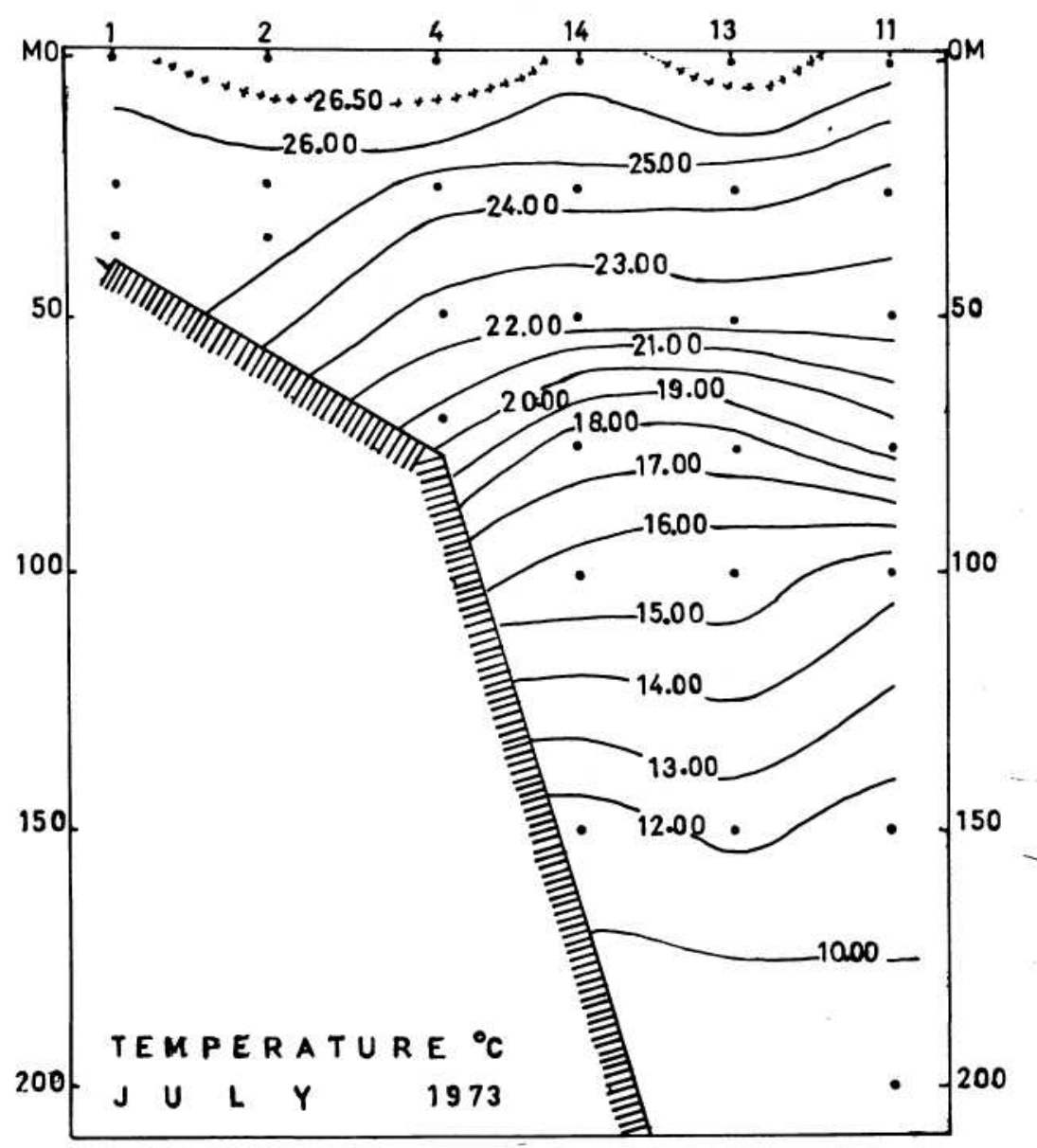

Cross Section of temperature in the Bali Strait in July 1973. 


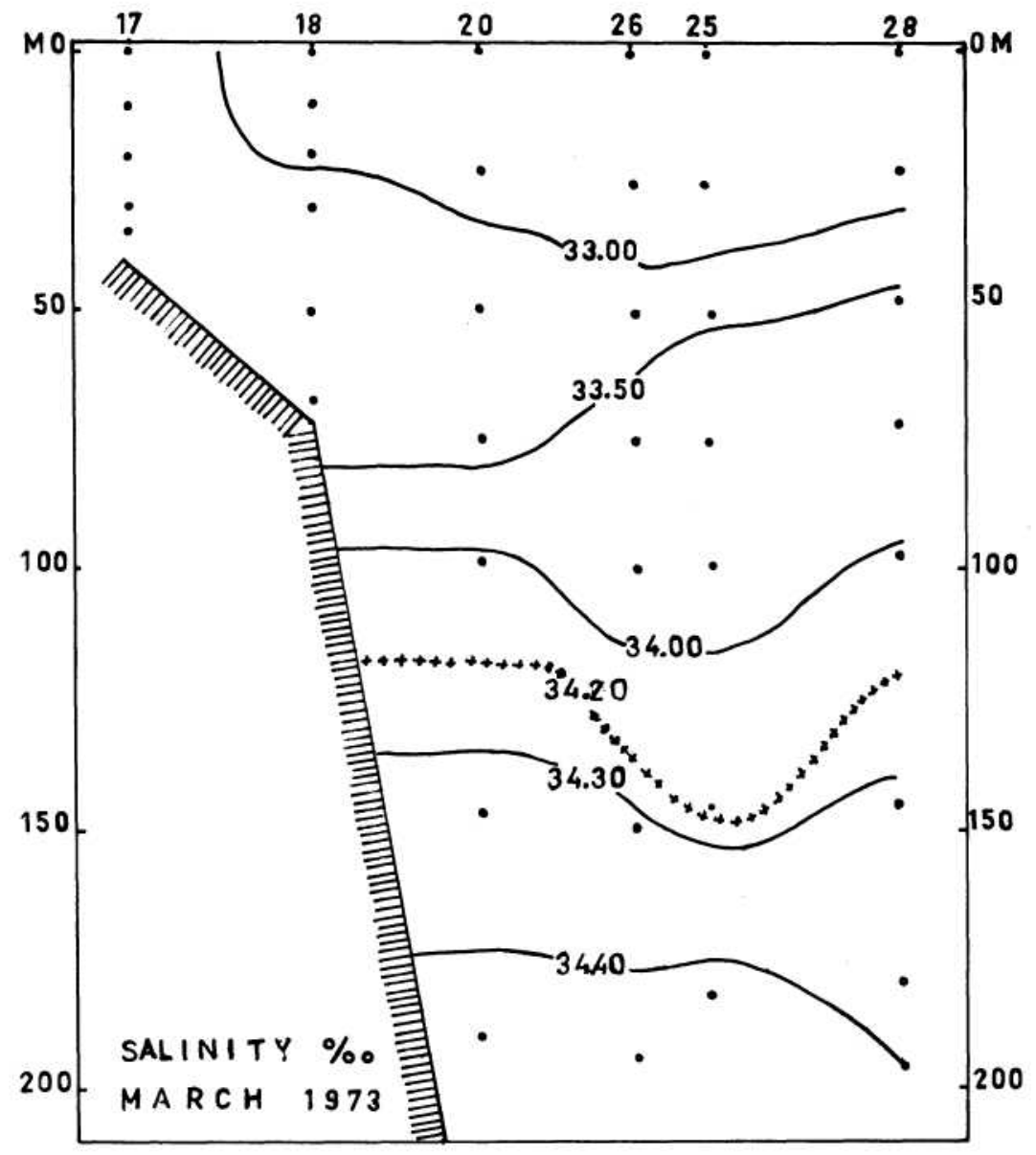

Cross Section of salinity in the Bali Strait in March 1973. 


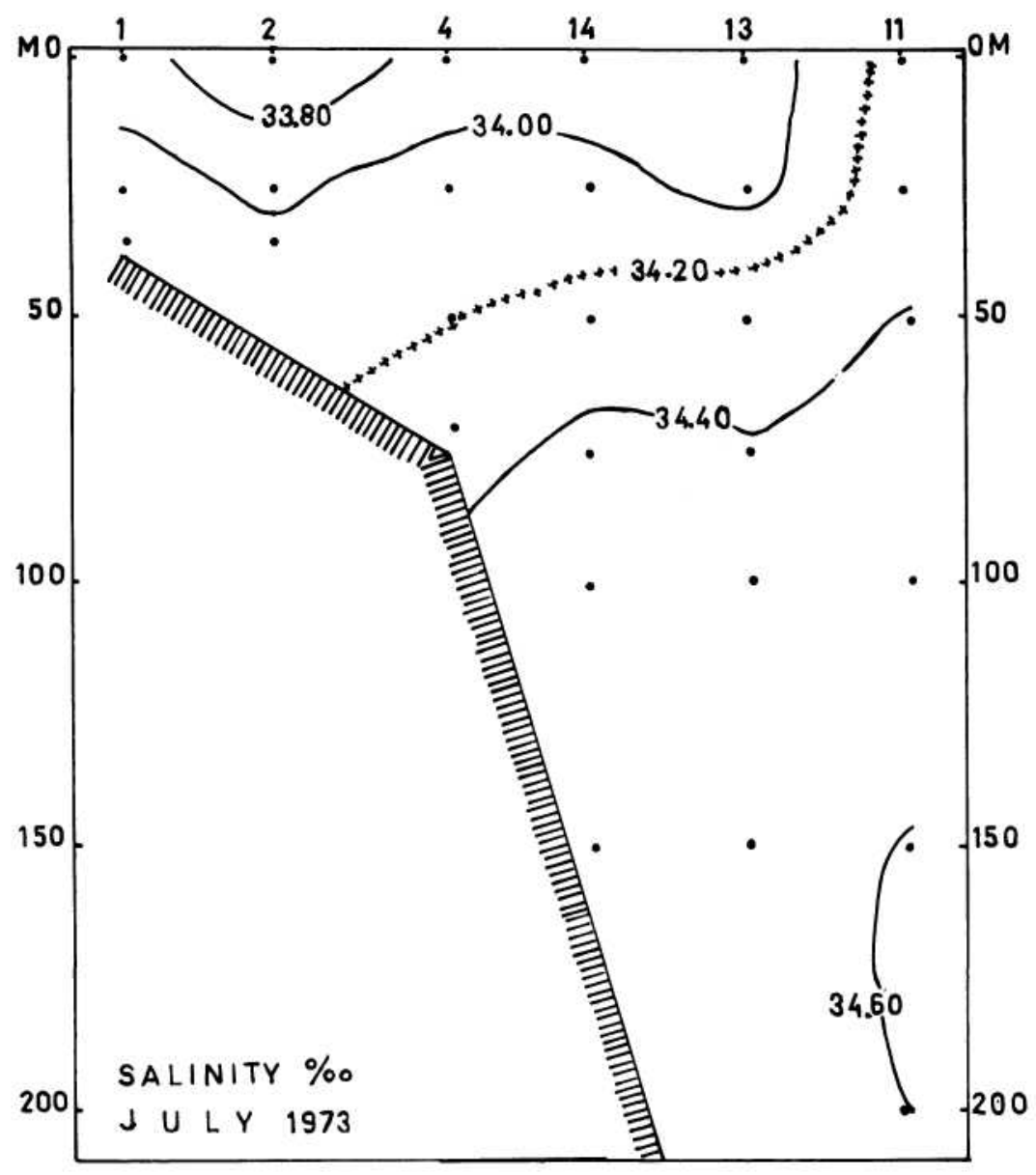

Cross Section of salinity in the Bali Strait in July 1973. 


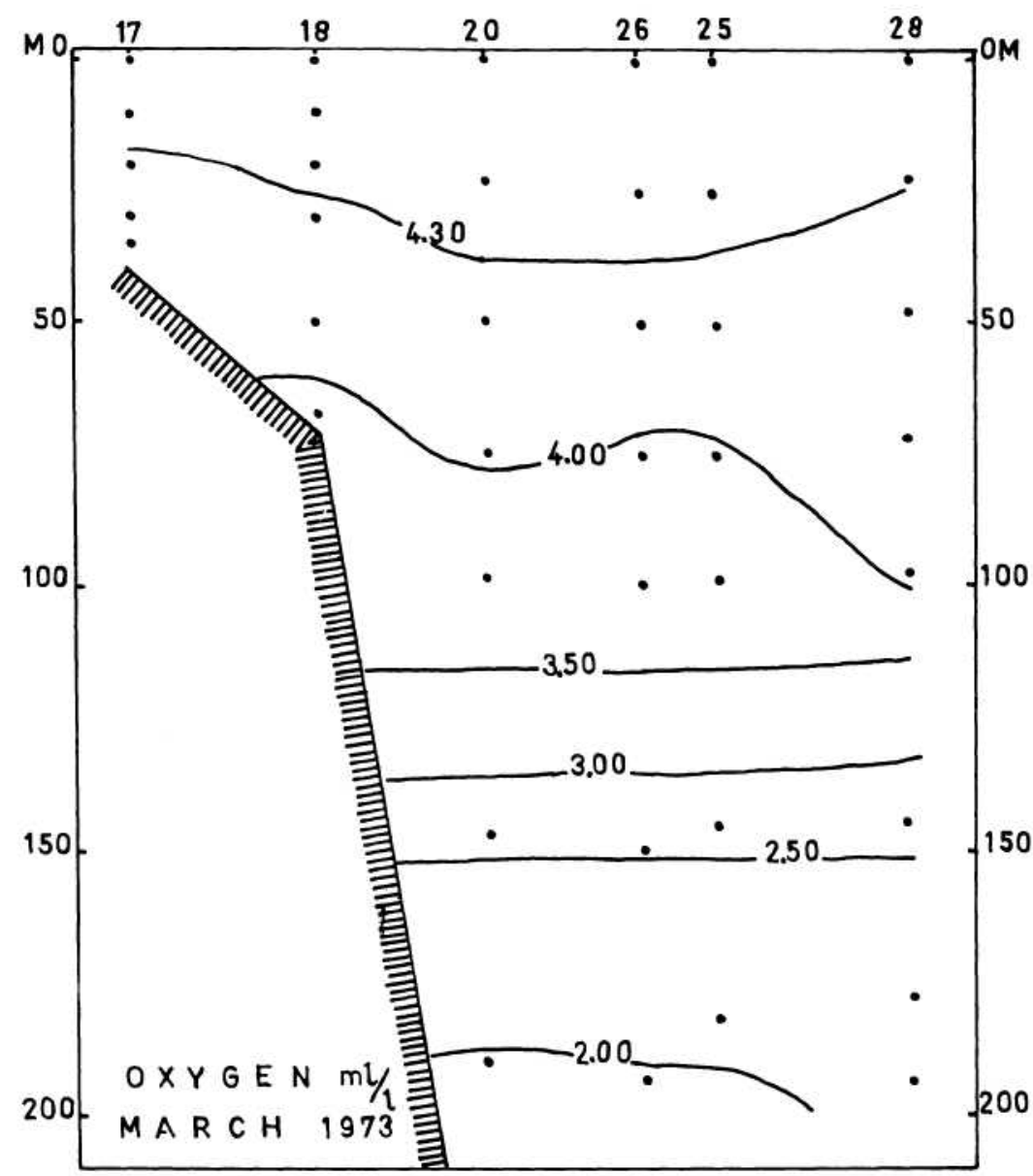

Cross Section of dissolved oxygen in the Bali Strait in March 1973. 
MaR. RES. Indonesia 15

Plate 8

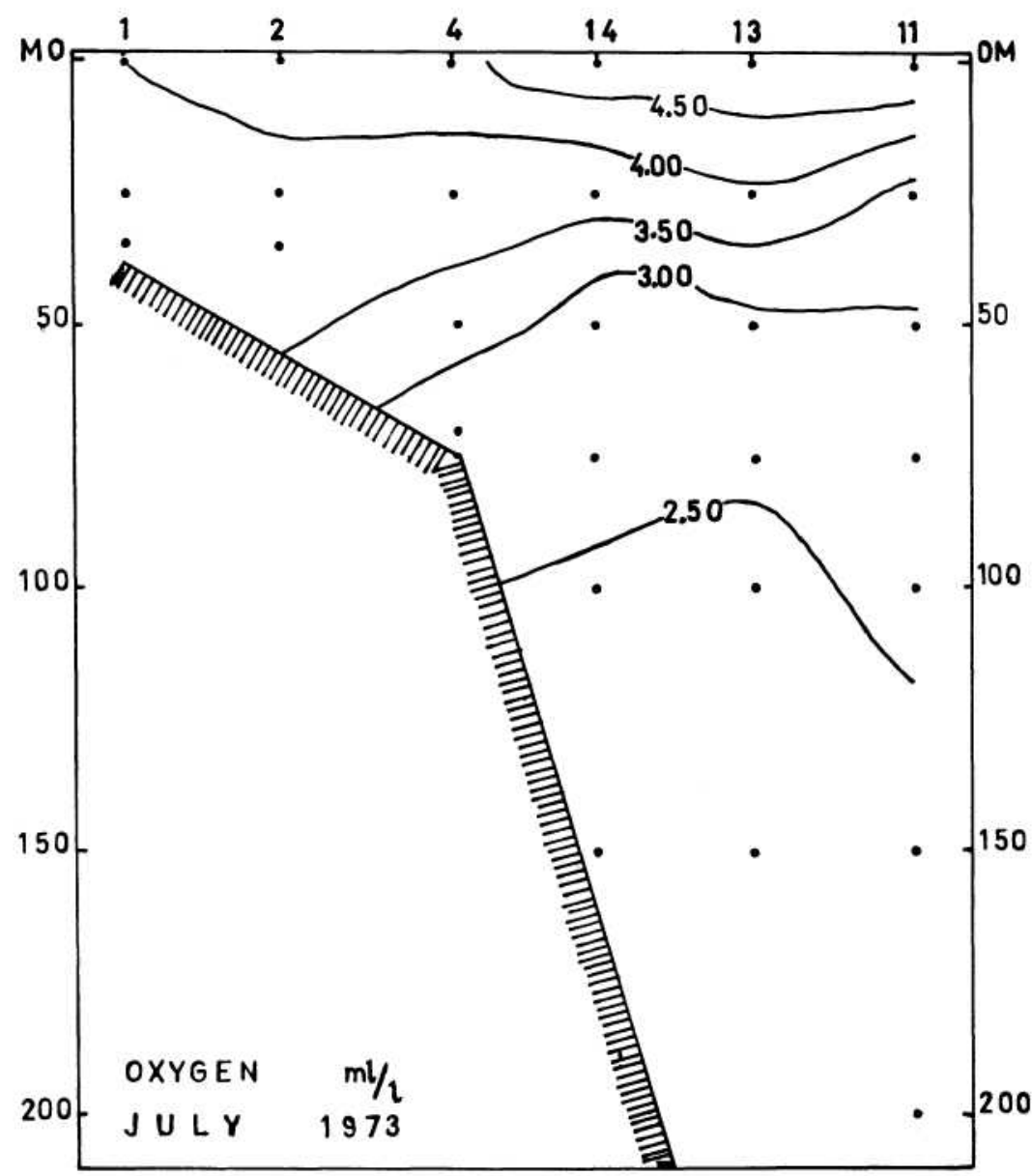

Cross Section of dissolved oxygen in the Bali Strait in July 1973. 


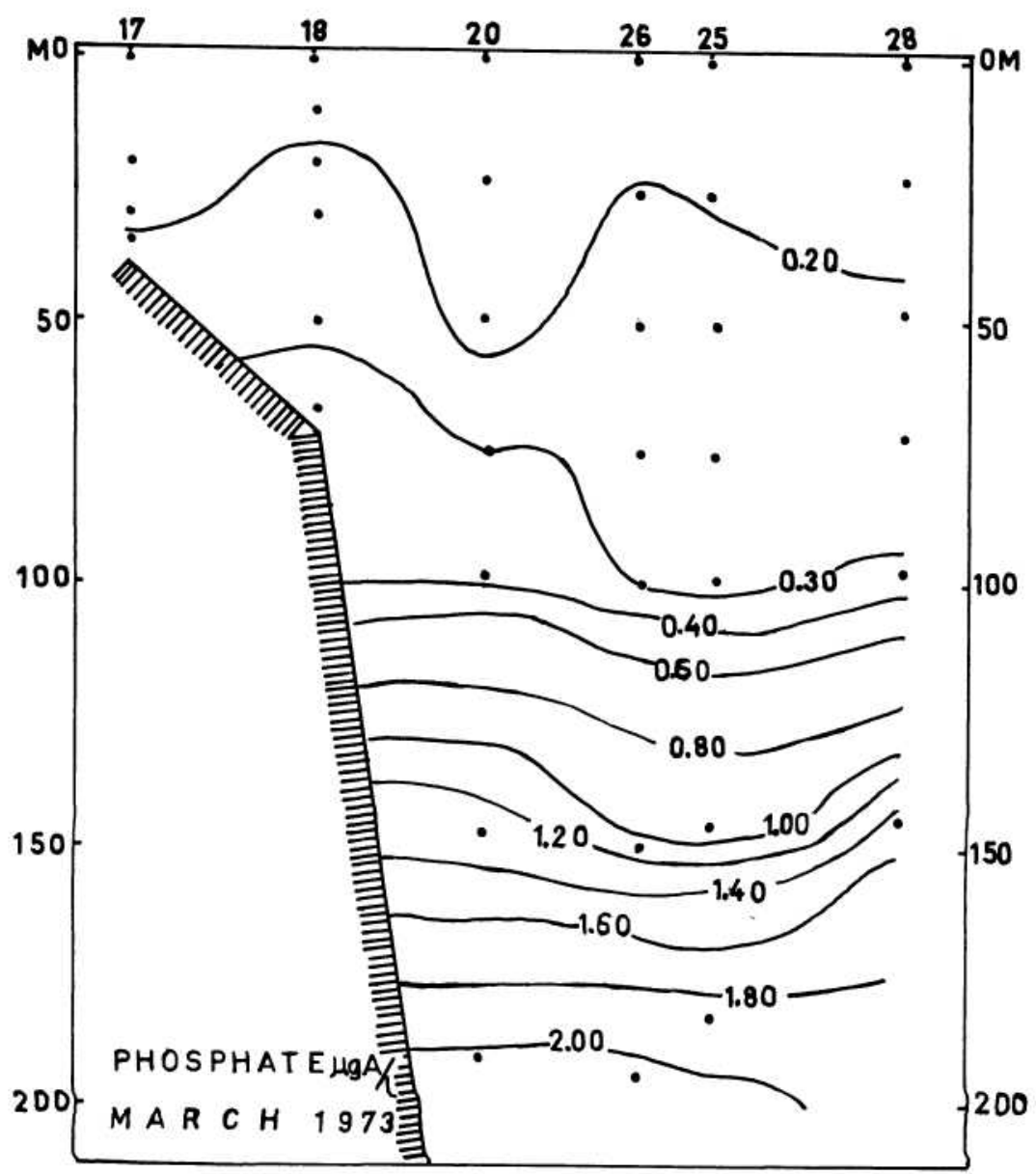

Cross Section of phosphate in the Bali Strait in March 1973. 


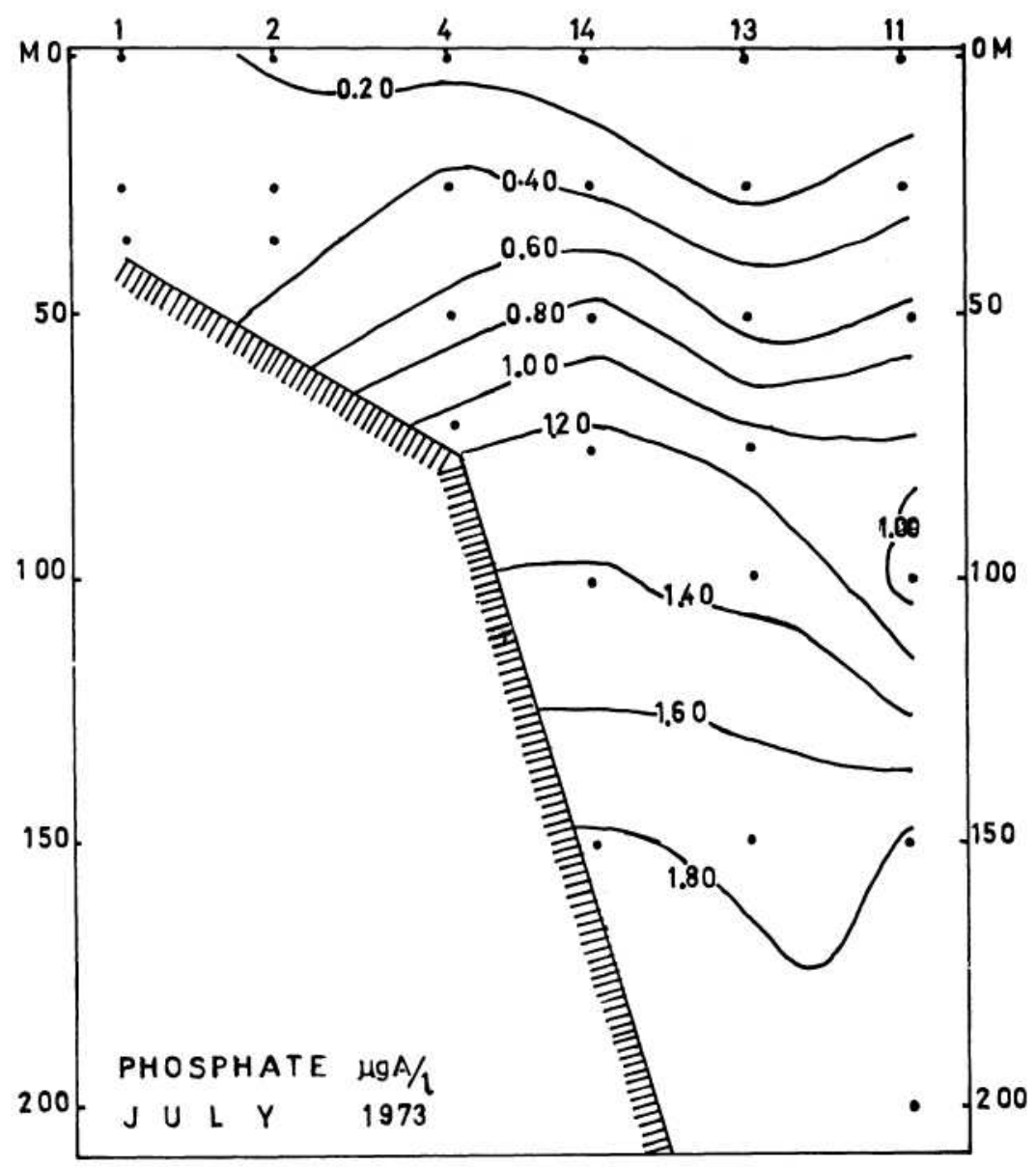

Cross Section of phosphate in the Bali Strait in July 1973. 
70

MAR. RES. INDONESIA 15

Plate 11

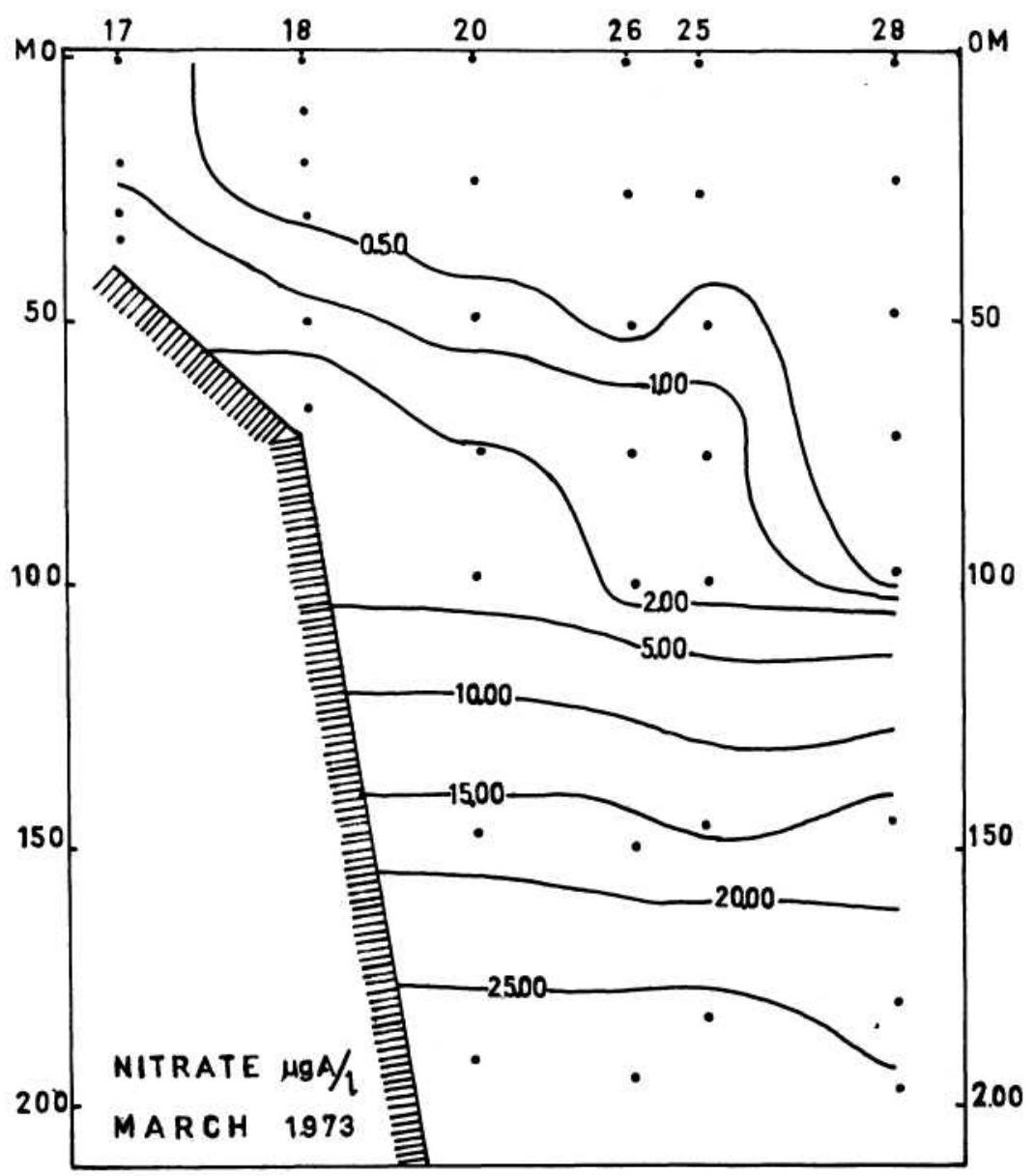

Cross Section of nitrate in the Bali Strait in March 1973. 


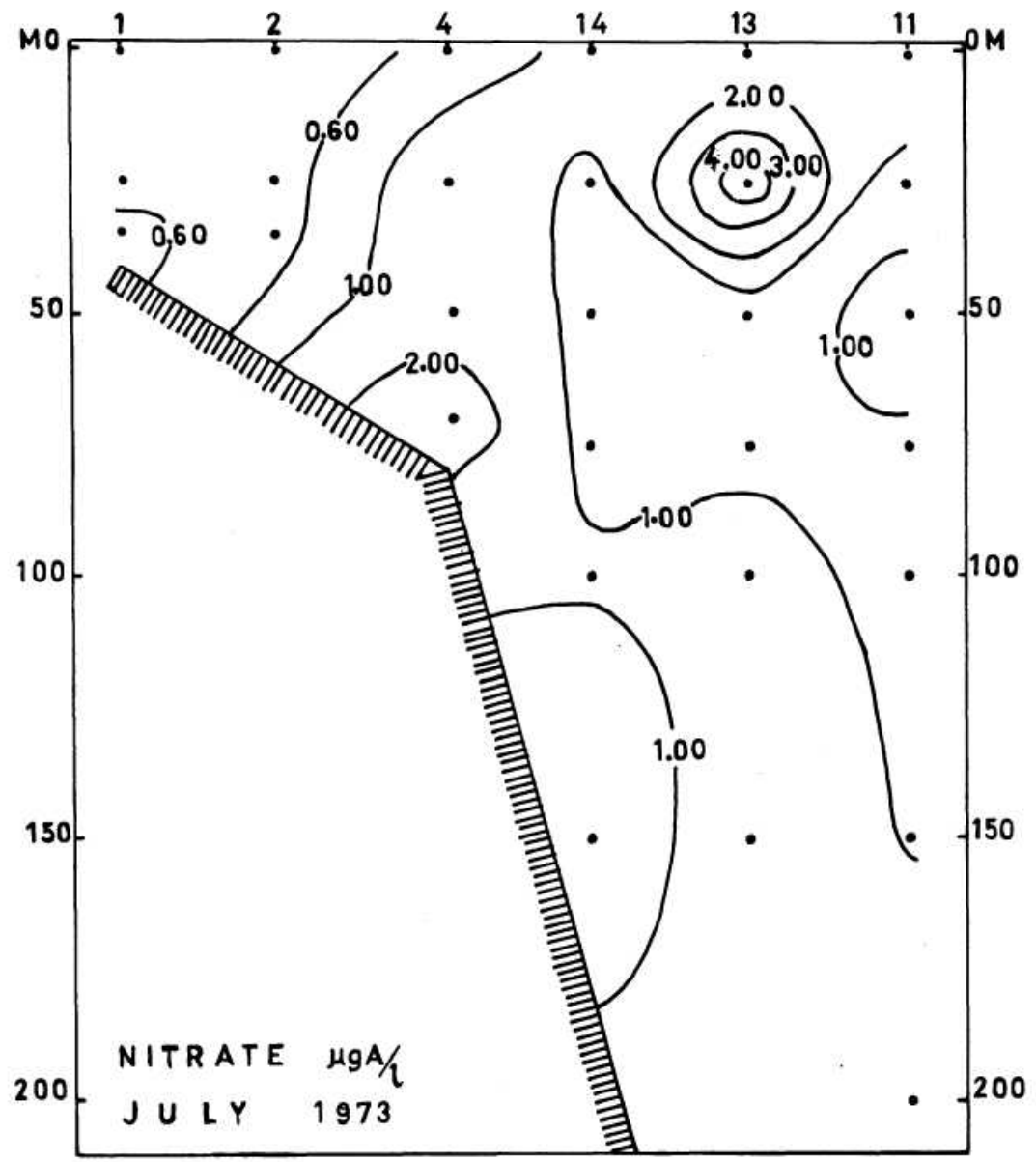

Cross Section of nitrate in the Bali Strait in July 1973. 


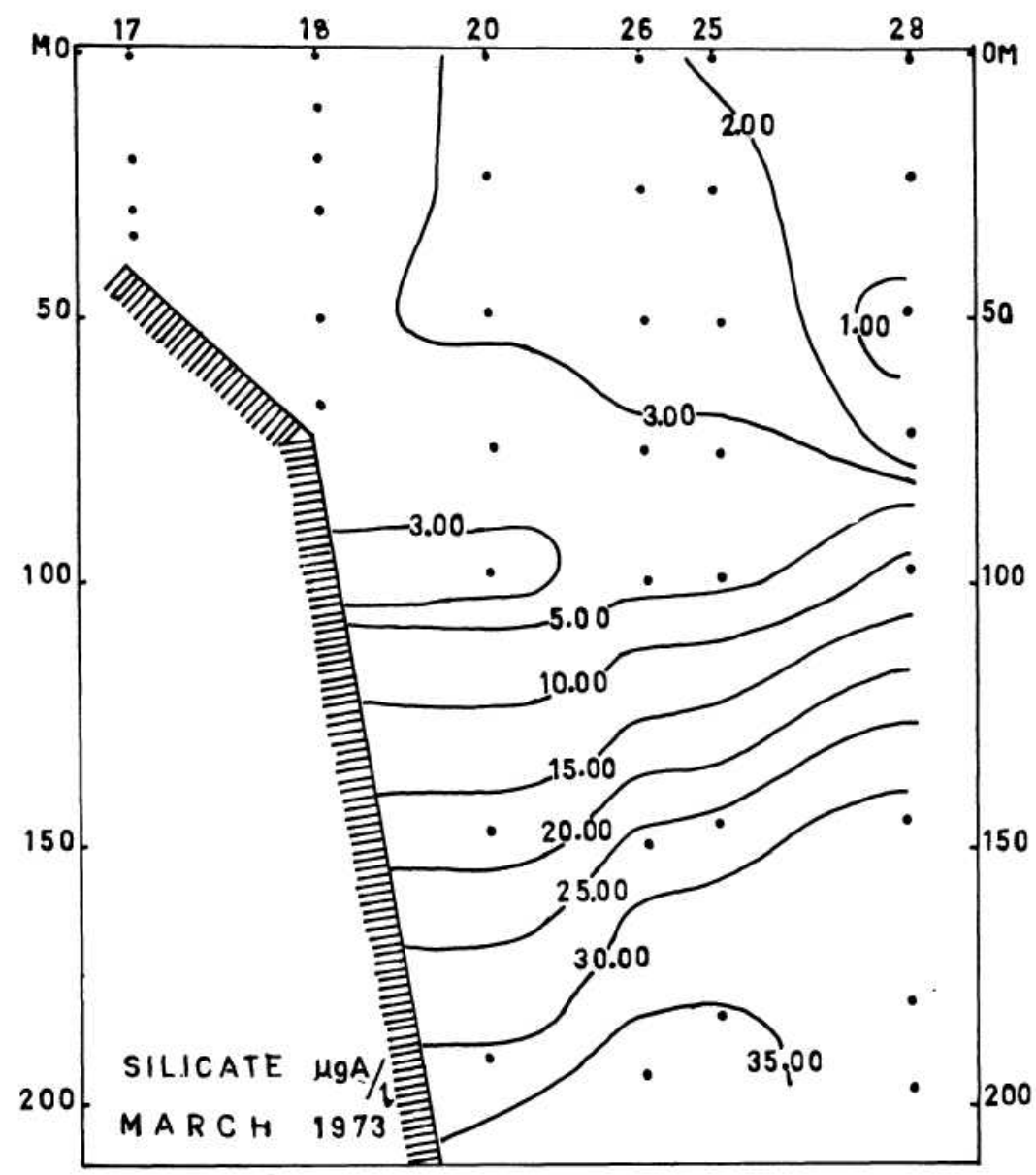

Cross Section of silicate in the Bali Strait in March 1973. 


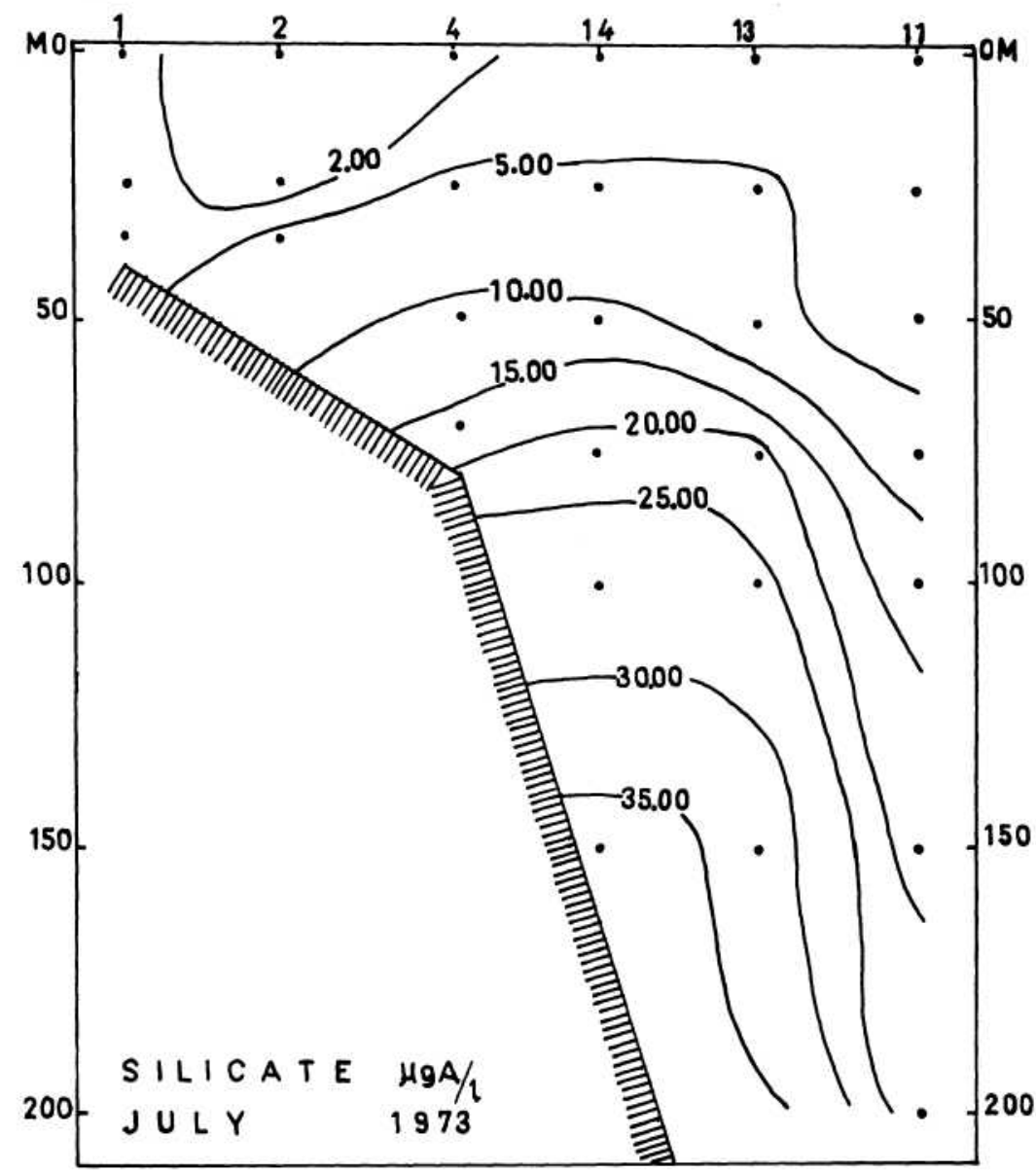

Cross Section of silicate in the Bali Strait in July 1973. 